\title{
PROTEÇÃO AO MEIO AMBIENTE E DESENVOLVIMENTO SUSTENTÁVEL
}

\author{
RICARDO LUPION*
}

\begin{abstract}
RESUMO: Este artigo propõe avaliar a importância do desenvolvimento econômico e o papel da empresa no modelo econômico nacional, a partir dos direitos fundamentais, com o objetivo de oferecer critérios para o adequado balanceamento entre esse desenvolvimento e a preservação ambiental em um mundo globalizado e em um Estado socioambiental. PALAVRAS-CHAVE: Desenvolvimento Sustentável; Meio ambiente; Empresa.
\end{abstract}

\begin{abstract}
This article proposes an evaluation of the economical development's importance and the company's role in the national economic model, based on the fundamental rights, aimed at offering criteria for the adequate balancing between such development and the environmental preservation in a globalized world and in a Socioenvironmental State.

KEYWORDS: Sustainable Development; Environment; Company.
\end{abstract}

SUMÁRIO: 1. Introdução: delimitação do tema. 2. Direitos Fundamentais: breve sobrevôo da origem à CF de 1988. 3. Meio Ambiente. O ser humano, a natureza e o progresso. 4. Desenvolvimento. 4.1. O modelo econômico na CF de 1988 e a empresa. 4.2. A práxis solidária da empresa. 4.3. Algumas fórmulas para neutralizar ou reduzir os efeitos da atividade econômica sobre o meio ambiente: funções e efeitos. 5. Globalização. 5.1. Impactos no Estado socioambiental. 5.2. O exemplo alemão. 6. Desenvolvimento sustentável: Significado, dimensões e fatores a ponderar. 7. Conclusões.

SUMMARY: 1. Introduction: outlining the subject; 2. Fundamental Rights: brief overview from the origin to the Federal Constitution of 1988; 3. Environment. The human being, nature and progress; 4. Development; 4.1. The economic model in the Federal Constitution of 1988 and the company; 4.2. The company's charital practice; 4.3. Some formulas to neutralize the economic activity's effects on the environment: functions and effects. 5. Globalization; 5.1. Impacts on the Socioenvironmental State. 5.2. The German example; 6. Sustainable development: Meaning, dimensions and pondering factors; 7. Conclusions.

\section{INTRODUÇÃO: DELIMITAÇÃO DO TEMA}

A proteção do meio ambiente em face do desenvolvimento e do progresso traz à baila a seguinte indagação: qual o grau aceitável de apropriação dos recursos da natureza em prol do desenvolvimento? A resposta tem passagem obrigatória pelo tema

\footnotetext{
* Mestre e Doutorando em Direito na Faculdade de Direito da PUCRS. Professor de Direito Empresarial na Faculdade de Direito da PUCRS e na Escola Superior da Magistratura do RS. Advogado Empresarial.
} 
dos direitos fundamentais e deve surgir do embate das forças do direito a livre iniciativa, liberdade de empreender e desenvolvimento com a necessidade de proteção ao meio ambiente e da valorização do trabalho humano.

O presente trabalho propõe avaliar a importância do desenvolvimento econômico como fator decisivo para o crescimento da taxa de emprego e, conseqüentemente, da melhoria de vida das pessoas e, ainda, quando necessário, as repercussões do desenvolvimento e do progresso em relação ao meio ambiente.

2. DIREITOS FUNDAMENTAIS: BREVE SOBREVÔO DA ORIGEM À CF DE 1988

É possível afirmar que os postulados da Revolução Francesa, hoje tão severamente criticados, representaram, à época, certa expressão de direitos fundamentais. ${ }^{1}$ A liberdade e a igualdade conquistada pela burguesia contra as monarquias absolutistas do Ancien Règime garantiram a todos uma esfera de atuação livre e contra o Estado. ${ }^{2}$

Após doloroso período de absolutismo, o espírito e o esforço particular foram valorizados com autonomia em cenário edificado nos alicerces da personalidade individual, em cujo sistema a vida concentrou-se na única tarefa de proteger o indivíduo contra a opressão estatal, garantindo plena autonomia do indivíduo frente à comunidade social. O liberalismo teve o mérito inegável de reconhecer o valor da vida humana, até então colocado à parte e, em especial, de haver contribuído, em todas as áreas, para o alargamento da noção de liberdade, conforme destacou Alexandre Pasqualini. ${ }^{3}$

Ingo Sarlet após esclarecer que os direitos fundamentais podem ser abordados sob a perspectiva filosófica, universalista e estatal ${ }^{4}$, prefere a visão constitucional que melhor atende aos aspectos da sua eficácia.

Apesar da existência de diversas tentativas de reconhecimento de direito fundamental ao longo da história o autor esclarece que essas tentativas não foram suficientes porque lhes faltaram o requisito essencial de vincular o Parlamento, muito

\footnotetext{
${ }^{1}$ Reitera-se a afirmação “certa expressão de direitos fundamentais” em homenagem à autoridade da posição de Ingo Sarlet ao sustentar que essa "tríade queda incompleta em não se fazendo a devida referência ao mais fundamental dos direitos, isto é, à vida e ao princípio fundamental da dignidade da pessoa humana”. Ingo Wolfgang Sarlet. A Eficácia dos direitos fundamentais. 6. ed. rev. atual. ampl. Porto Alegre: Livraria do Advogado, 2006, p. 65.

${ }^{2}$ Para Ingo Sarlet existem diversas dimensões de direitos fundamentais. Os de primeira dimensão, de cunho "negativo" porque representam um direito de "resistência ou oposição" frente ao Estado, como o direito à vida, à liberdade, à propriedade e à igualdade perante a lei. Também estão inseridos nesta categoria de primeira dimensão o "leque de liberdades” do cidadão (liberdade de expressão, política, reunião, associação), diretos de participação política e as garantias processuais do devido processo legal, habeas corpus e direito de petição”. Obra citada. p. 55 e seguintes.

${ }^{3}$ Alexandre Pasqualini. "Reflexões para uma tese sobre o público e o privado". Revista da Ajuris, vol. 45, p. 63.

${ }^{4}$ A partir da lição do jurista lusitano Vieira de Andrade, o autor enumera: “a) perspectiva filosófica (ou jusnaturalista), a qual cuida do estudo dos direitos fundamentais como direitos de todos os homens, em todos os tempos e lugares; b) perspectiva universalista (ou internacionalista) como direitos de todos os homens (ou categorias de homens) em todos os lugares, num certo tempo; c) e perspectiva estatal (ou constitucional), pela qual os direitos fundamentais são analisados na qualidade de direitos dos homens, num determinado tempo e lugar”. Idem; p. 26.
} 
embora todas tenham influenciado a Declaração dos Direitos do Homem de 1783 que, por sua vez, reconheceu a todos os homens direitos invioláveis e imprescritíveis. ${ }^{5}$

A característica principal e distintiva entre direitos fundamentais e direitos humanos é a oponibilidade contra os detentores do poder estatal. Enquanto aqueles derivam de uma ordem jurídica constitucional vinculando todos, inclusive o poder estatal, estes possuem dimensão internacional já que decorrem de tratados internacionais que nem sempre resultam acolhidos pelo sistema jurídico de todas as nações.

Ao tratar da controvérsia em torno da distinção entre direitos humanos e direitos fundamentais, Ingo Sarlet adverte que os direitos humanos possuem "contornos mais amplos e imprecisos" e os direitos fundamentais:

“[...] possuem sentido mais preciso e restrito, na medida em que constituem o conjunto de direitos e liberdades institucionalmente reconhecidos e garantidos pelo direito positivo de determinado Estado, tratando-se, portanto, de direitos delimitados espacial e temporalmente, cuja denominação se deve ao seu caráter básico e fundamentador do sistema jurídico do Estado de Direito”. ${ }^{6}$

A necessidade de proteger em elevado grau a dignidade da pessoa humana surge após os conflitos armados das duas guerras mundiais, tão aviltada e desrespeitada pelos regimes ditatoriais durante o segundo conflito mundial. ${ }^{7}$

${ }^{5}$ Idem. p. 48 e seguintes.

${ }^{6}$ Idem. (p. 38). Em outra passagem Ingo Sarlet afirma que "não há dúvidas de que os direitos fundamentais, de certa forma, são também sempre direitos humanos, no sentido de que seu titular sempre será o ser humano” (p. 35). Ocorre que o “catálogo dos direitos fundamentais na Constituição-Cidadã de 1988”, na feliz expressão do autor (p. 75), contém rol de direitos fundamentais de que são titulares não somente o ser humano, mas também as pessoas jurídicas, cuja existência está expressamente reconhecida no Código Civil de 2002 (Parte Geral, Livro I, das pessoas, Título II, das pessoas jurídicas, art. 40 e seguintes). Veja-se, por exemplo, que dentre os direitos fundamentais de "primeira dimensão" elencados em sua conhecida e prestigiada obra (p. 56) os direitos à propriedade, à igualdade perante a lei, à liberdade de expressão, imprensa, manifestação, associação e as garantias processuais (devido processo legal, direito de petição) são direitos fundamentais assegurados às pessoas jurídicas e, portanto, não seriam sempre de titularidade de seres humanos. Também para o jurista espanhol Francisco Segado o princípio da dignidade humana é uma qualidade "ínsita a todo ser humano y exclusiva del mismo.” Todavia, ao elencar os níveis e dimensões da dignidade da pessoa humana, o autor relaciona dois deles que também são atribuíveis às pessoas jurídicas, quais sejam “[...] c/ la dimensión ética, em el sentido de autonomía moral, no absoluta, pero si como esencial función de la conciencia valorativa ante cualquier norma y cualquier modelo de conducta; y esfuerzo de liberación frente a interferências o presiones alienantes y de manipulaciones cosificadoras, y d/ la dimensión social, como estima y fama dimanante de um comportamiento valioso, privado o público, em la vida de relación.”. Francisco Fernández Segado. "La dignidad de la persona como valor supremo del ordenamiento jurídico español y como fuente de todos los derechos”. Jurisdição e direitos fundamentais: anuário 2004/2005 - Escola Superior da Magistratura do Rio Grande do Sul-AJURIS; coord. Ingo Wolfgang Sarlet - Porto Alegre: Escola Superior da Magistratura: Livraria do Advogado, 2006, vol. 1, t.2, p. 110. No âmbito do processo civil, os direitos fundamentais também seriam de titularidade das pessoas jurídicas "devido processo legal (art. 5º incisos XXXVII e LII), a igualdade (art. $5^{\circ}$, caput), aí compreendida a paridade de armas, o contraditório e a ampla defesa, com os meios e recursos a ela inerentes (art. $5^{\circ}$, inciso LV), consideradas inadmissíveis as provas obtidas por meios ilícitos (art. 5 , inciso LVI), devendo o litígio ser solucionado por meio de decisão fundamentada (art. 94, inciso IX)". Carlos Alberto Alvaro de Oliveira. "O Processo Civil na perspectiva dos direitos fundamentais” Jurisdição e direitos fundamentais...., p. 262.

7 "Los horrores de la Segunda Guerra Mundial impactarían de tal forma sobre el conjunto de la humanidad, que por doquier se iba a generalizar un sentimiento de rechazo, primero, y de radical rectificación después, que había de conducir en una dirección que entendemos sintetiza con una meridiana claridad el primer 
Após fazer um minucioso relato do sistema de direitos fundamentais no direito alemão a partir da formulação de Düring (para quem o sistema seria isento de lacunas), Ingo Sarlet, com a sua reconhecida autoridade sobre o tema, refere a posição sustentada por K. Hesse no sentido de que os direitos fundamentais estão dispersos no texto constitucional e, consequentemente, não é possível reconhecer a "existência de um sistema autônomo, fechado (no sentido de isento de lacunas)."8

No âmbito do direito constitucional brasileiro, Sarlet aceita a posição de Hesse em especial pela existência de direitos fundamentais "fora do catálogo"9 concluindo, nesse sentido, que direitos fundamentais são:

“Todas aquelas posições jurídicas concernentes às pessoas, que, ponto de vista do direito constitucional positivo, foram, por seu conteúdo e importância (fundamentalidade em sentido material), integradas ao texto da Constituição e, portanto, retiradas da esfera de disponibilidade dos poderes constituídos (fundamentalidade formal), bem como as que, por seu conteúdo e significado, possam lhes ser equiparados, agregando-se à Constituição material, tendo, ou não, assento na Constituição formal (aqui considerada a abertura material do Catálogo)”. 10

Reconhecida a existência de direitos fundamentais fora do "catálogo" do Capítulo II - Dos Direitos e Garantias Fundamentais da Carta Constituição Federal, no âmbito do presente trabalho, se desenvolverá o cotejo do direito fundamental ao meio ambiente inserto no art. 225 segundo o qual "todos têm direito ao meio ambiente ecologicamente equilibrado" com o princípio que rege a ordem econômica inserto no art. 170 que também assegura a todos a liberdade de empreender e de exercer atividade econômica "fundada na valorização do trabalho humano e livre iniciativa”, cuja tarefa, evidentemente, impõe desafios e sacrifícios.

3. MEIO AMBIENTE: O SER HUMANO, A NATUREZA E O PROGRESSO

Insta analisar o alcance da conhecida expressão segundo a qual o homem depende da natureza para sobreviver. Em que medida essa dependência da natureza deve orientar as ações humanas sobre o meio ambiente?

Essa dependência sempre deve representar exclusivamente uma limitação para

párrafo del Preámbulo de la Declaración Universal de Derechos Humanos de 10 de diciembre de 1948”. Francisco Fernández Segado. Obra citada, p. 99. Em seguida o mesmo autor indica os seguintes países que consagraram o princípio da dignidade da pessoa humana: Constituição de Massachusetts, Constituição Japonesa, Constituição da República Islâmica do Iran, Constituição do Peru, Constituição da Guatemala, Constituição da Itália, Lei Fundamental de Bonn (Alemanha), Constituição de Portugal e Constituição da Espanha. Ingo Sarlet ao abordar o tema da "positivação do princípio da dignidade da pessoa humana”, também lança "um olhar sobre o direito comparado" e faz um relato dos países, cujos textos constitucionais reconheceram expressamente o princípio da dignidade da pessoa humana. Obra citada, p. 113. Cláudio Ari Melo refere ao "processo de constitucionalização dos direitos sociais”. "Os direitos fundamentais sociais e o conceito de direito subjetivo”. Revista do Ministério Público do Rio Grande do Sul, n 56, set/dez 2005, p. 106.

${ }^{8}$ Idem. p. 84

${ }^{9}$ A feliz expressão "catálogo dos direitos fundamentais" cunhada pelo prestigiado autor refere-se ao rol contido no art. $5^{\circ}$ da Carta Magna. Em outra passagem, Sarlet reconhece a existência de direitos fundamentais "fora do catálogo", como por exemplo, a proteção ao meio ambiente. Idem, p. 138.

${ }^{10}$ Idem, p. 91 
frear a ação do homem sobre o meio ambiente? Deve, também, ter a conotação de garantir a sobrevivência do ser humano da qual pode resultar certa apropriação do meio ambiente pelo homem como forma de assegurar e promover a sua existência?

Essa conotação de sobrevivência não escapou à Conferência das Nações Unidas sobre o Meio Ambiente e Desenvolvimento, conhecida como ECO 92 (Rio de Janeiro, 14 de junho de 1992) ao consagrar no princípio n 1 que "os seres humanos estão no centro das preocupações com o desenvolvimento sustentável. Têm direito a uma vida saudável e produtiva, em harmonia com a natureza”.

A louvável valorização e preocupação com o futuro não pode acarretar a negação das condições mínimas de existência, progresso e desenvolvimento do ser humano. A preocupação com o futuro não pode resultar na desconsideração do hoje ou, por outras palavras, o progresso e o desenvolvimento podem justificar certa degradação ambiental, ${ }^{11}$ como, por exemplo, mas a eles não se limitando, desmatamentos provocados pela instalação de atividades industriais geradoras de emprego ou pelo loteamento de terras para construção de moradias populares nem sempre regulares.

A ordem econômica, na locução do art. 170 da Carta Política, é fundada na valorização do trabalho humano e tem por fim assegurar a todos existência digna, observados os princípios da defesa do meio ambiente (VI), da redução das desigualdades regionais e sociais (VII) e a busca do pleno emprego (VIII), razão pela qual a defesa do meio ambiente não deve ser hierarquizada em posição sempre superior e também não pode constituir valor absoluto já que as atividades econômicas também visam atender aos demais princípios insertos no referido dispositivo constitucional. ${ }^{12}$

Dentre os diversos princípios que regem o direito ambiental, o princípio da precaução interage ou interfere diretamente no desenvolvimento econômico. Referido

\footnotetext{
${ }^{11}$ Annelise Steigleder com apoio no jurista argentino Iturraspe comenta "se a opção é pelo desenvolvimento, em que se pratica a economia de mercado em todas as suas possibilidades, o dano ambiental que dá margem ao ressarcimento é minimizado, o que se faz mediante o estabelecimento de margens de tolerância quanto aos impactos ambientais, pela distinção entre dano excessivo e dano abusivo e ilícito, e pela admissão de determinados tipos de poluição, justificados pelo progresso.” Annelise Monteiro Steigleder. Responsabilidade civil ambiental: as dimensões do dano ambiental no Direito brasileiro. Porto Alegre: Livraria do Advogado, 2004, p. 46. Em outra passagem a autora destaca que "em sociedades em que a sensibilidade para questões ecológicas encontra-se desenvolvida, a própria opinião pública não permitira que as degradações ambientais permaneçam sem reparação.” (p. 62). Trata-se, na verdade, de sociedades que já solucionaram as mazelas decorrentes da falta de desenvolvimento (saúde, educação, trabalho, assistência social, entre outras). Mas é preciso estar atento para os efeitos do crescimento a qualquer custo: "Fundava-se tal perspectiva (de crescimento a qualquer custo) equivocada na idéia de que as nações subdesenvolvidas e em desenvolvimento, por enfrentarem problemas socioeconômicos de grande gravidade, não deveriam desviar recursos para proteger o meio ambiente. A poluição e a degradação do meio ambiente eram vistas como um mal menor. [...] “essa opção de crescer a qualquer custo levou o brasileiro a uma impiedosa agressão à natureza”. Edis Milaré. Direito do Ambiente: doutrina, prática, jurisprudência, glossário. 2. ed. rev. atual. e ampl. São Paulo: Ed. RT, 2001, p. 40.

${ }^{12}$ A respeito da posição do ser humano em relação ao meio ambiente cabe referir a advertência de Edis Milaré. "Tanto a Lei $\mathrm{n}^{\circ}$ 6.938/81 quanto a Lei Maior omitem-se sobre a consideração essencial de que o ser humano, considerado como indivíduo ou como coletividade, é parte integrante do mundo natural e, por conseguinte, do meio ambiente. Esta omissão pode levar facilmente à idéia de que o ambiente é algo extrínseco e exterior à sociedade humana, confundindo-o, então, com seus componentes físicos bióticos e abióticos, ou com recursos naturais e ecossistemas”. Obra citada, p. 66.
} 
princípio, do ponto de vista da proteção ambiental, é mais rigoroso do que o princípio da prevenção. Peter Montague esclarece que

the precautionary principle is a new way of making decisions about environment and health. The purpose of the precautionary approach is to make decisions today that we will not regret in 50 years. As the precautionary approach becomes better known, it is being studied and criticized, which is normal for new ideas. ${ }^{13}$

Montague refere aos princípios da precaução e da prevenção respectivamente como new way e old way e aponta a substancial a diferença: the precautionary approach responds in a new way to risks. As we saw above, the old way asks how much harm is acceptable? The precautionary approach asks, How much harm is avoidable? para concluir com o slogan Better safe than sorry. ${ }^{14}$

A Conferência das Nações Unidas sobre o Meio Ambiente e Desenvolvimento, a ECO 92 (Rio de Janeiro, 14 de junho de 1992) referiu a precaução no princípio n ${ }^{\circ} 15$ ao estabelecer que para proteger o meio ambiente "medidas de precaução devem ser largamente aplicadas pelos Estados, segundo suas capacidades. Em caso de riscos de danos graves e irreversíveis, a ausência de certeza científica absoluta não deve servir de pretexto para procrastinar a adoção de medidas visando a prevenir a degradação do meio ambiente”.

Entre nós José Leite e Patryck Ayala comentam que é possível estabelecer a distinção na aplicação dos princípios da prevenção e da precaução entre perigo e risco, respectivamente. ${ }^{15}$ Para Cristiane Derani, trata-se de uma "precaução contra o risco, que objetiva prevenir já uma suspeição de perigo ou garantir uma suficiente margem de segurança da linha de perigo". ${ }^{16}$ Leite e Ayala sustentam que o objetivo fundamental na aplicação do princípio da prevenção é "a proibição da atividade que já se sabe perigosa” enquanto a precaução incide "quando a incerteza científica não permite uma avaliação completa dos riscos e as instâncias de decisão consideram que pode existir uma ameaça ao nível escolhido de proteção do ambiente". ${ }^{17}$

Para afastar exageros que poderiam resultar da incorreta compreensão da frase criada pela genialidade do Sunstein de que "as pessoas não gostam de correr um pequeno risco de uma grande ou catastrófica perda”"18 o princípio da precaução não pode ser fruto de "temores excessivos ou desarrazoados” exigindo “motivação consistente”

\footnotetext{
${ }^{13}$ Peter Montague. Answering the Critics of Precaution. Disponível em <http://www.rachel.org/library/ Getfile.cfm?ID=378>, acesso em 20.ago.2006.

${ }^{14}$ Tradução livre: “é melhor prevenir do que remediar”. Idem. Ibidem.

${ }^{15}$ José Rubens Morato Leite, Patrick de Araujo Ayala. Direito ambiental na sociedade de risco. 2. ed. Rio de Janeiro: Forense Universitária, 2004, p. 71 e seguintes. Os autores também sustentam que "o preço e os custos da segurança” não podem ser determinados pelas instituições e pelos especialistas e só podem ser decididos no espaço público com elevada participação democrática. Os conflitos decorrentes da aplicação desses princípios devem ser resolvidos "mediante a atuação restritiva e integradora dos princípios da proporcionalidade, proibição da discriminação, fungibilidade (modificabilidade), coerência e ponderação (balancing/abwagung). Idem, ibidem.

${ }^{16}$ Cristiane Derani. Direito Ambiental Econômico. São Paulo: Max Limonad, 1997, p. 165.

${ }^{17}$ Idem, ibidem.

${ }^{18}$ Cass R. Sunstein. “Para Além do Princípio da Precaução”. Revista Interesse Público, vol. 37, p. 119.
} 
de modo que a forte verossimilhança possa sustentar a ausência de certeza científica, conforme abalizada posição de Juarez Freitas. ${ }^{19}$

Além de motivado - continua Juarez - o exercício da precaução haverá de ser proporcional, isto é, com pertinência entre os meios escolhidos e os resultados colimados (subprincípio da adequação entre meios e fins), com adoção da alternativa que afete o menos possível os interesses e as liberdades em jogo (subprincípio da necessidade) e com adequação dos meios (subprincípio da proporcionalidade em sentido estrito). ${ }^{20}$

A ponderação entre o dano ambiental alegado pelo Ministério Público pela construção da Rodovia RS-786 “Estrada do Mar” porque teria atingido a mata nativa remanescente da Mata Atlântica e o progresso econômico e a melhoria das condições de vida propiciadas pela construção da rodovia conforme sustentou o Estado do Rio Grande do Sul em sua defesa, foi objeto da decisão do Tribunal de Justiça do Estado do Rio Grande do Sul nos seguintes termos:

“Qualquer obra do homem, por mais insignificante que seja, provoca sempre algum tipo de impacto negativo no meio-ambiente, pelo simples fato de que o altera. A obra se justifica, contudo, sempre que os benefícios dela decorrentes, traduzidos no bem-estar social, como segurança, conforto e saúde à coletividade, sejam maiores do que o impacto negativo por ela causado, mas não dispensa a compensação, ainda que por outra forma, do prejuízo causado. Não restando quantificado e comprovado o efetivo prejuízo alegado, mas, ao contrário, suplantados pelos evidentes benefícios, improcede o pedido de indenização formulado contra o construtor da obra, esta, no caso, uma via pública”. ${ }^{21}$

19 Juarez Freitas. "Princípio da Precaução: vedação de excesso e de inoperância”, Revista Interesse Público, vol. 35, p. 39 .

${ }^{20}$ Obra citada. pp. 42-46. O autor também sustenta que "a própria precaução, se e quando ruinosamente inflacionada, revela-se fator imobilizante que gera o pecado da omissão, em vez de vencê-lo. Precaução em demasia é não-precaução. E, para piorar as coisas, a paralisia irracional desencadeia danos juridicamente injustos e, portanto indenização” (p. 39). Ao final, Juarez faz adequada distinção entre a prevenção e a precaução com base em situações reais. Ainda sobre o princípio da proporcionalidade: Luis Roberto Barroso. "Os princípios da razoabilidade e da proporcionalidade no direito constitucional”. Cadernos de Direito Constitucional e Ciência Política.vol. 23, pp. 65-78. Humberto Bergmann Ávila. “A dintinção entre princípios e regras e a redefinição do dever de proporcionalidade”. Revista de Direito Administrativo. jan/mar. pp. 151-179. Gilmar Ferreira Mendes. "Proporcionalidade na Jurisprudência do Supremo Tribunal Federal”. Repertório IOB de jurisprudência n ${ }^{\circ}$ 23/94, pp. 474-469 e “O Princípio da Proporcionalidade na Jurisprudência do Supremo Tribunal Federal: Novas Leituras”. Repertório IOB de jurisprudência n 14/2000, pp. 372-361. Luís Virgilio Afonso da Silva. “O proporcional e o razoável”. Revista dos Tribunais, vol. 798, pp. 23-50.

${ }^{21}$ Do acórdão colhem-se as seguintes passagens : "Sempre que se tem em mira preservar valores naturais está-se, induvidosamente, diante de um interesse coletivo (de todas as pessoas), que, por sua vez, quando as circunstâncias o exigirem, pode vir a configurar interesse público (do Estado). Não é por nada que a atual Constituição Federal, em seu art. 225, dedica vários preceitos à matéria relativa ao meio-ambiente, impondo ao Poder Público e à coletividade o dever de defendê-lo e preservá-lo para as presentes e futuras gerações. [..] Todavia, uma evidência se impõe: é nesse meio ambiente que o homem vive, não como um ser primitivo, apenas usufruindo dos recursos naturais disponíveis, mas como um ser moderno e cada vez mais evoluído, que o leva ao aprimoramento do seu próprio meio, buscando, com isso, mais segurança, conforto e saúde, vale dizer, maior bem-estar social. O que não lhe é possível fazer direta e individualmente, o faz através do ente maior, que é o Estado, desde que, evidentemente, os danos ao meio-ambiente não sejam, em cada caso, maiores do que os benefícios decorrentes. [...] O que pretendeu o Estado, através do 
A aplicação desmedida e insensata do princípio da prevenção ou da precaução resultará no atraso do desenvolvimento, na paralisação das atividades produtivas e obsolescência da atividade industrial, gerando efeito paralisante do progresso tão caro e necessário para o ser humano. A proteção ao meio ambiente deve ser compatibilizada com outros valores também reconhecidos pela carta constitucional em igual posição hierárquica conforme adiante se verificará.

\section{DESENVOLVIMENTO}

\subsection{O modelo econômico na CF de 1988 e a empresa}

Em face da opção da Assembléia Nacional Constituinte de 1988 ao afastar o Estado do exercício das atividades econômicas, reservando-as para a iniciativa privada, a empresa, ao desenvolver as suas atividades, assume papel relevante para a melhoria das condições de vida dos cidadãos, propiciando condições para que os trabalhadores tenham salário digno, assistência à saúde e à previdência e educação, sobretudo para o pleno atendimento dos objetivos fundamentais declarados no pórtico da Carta Constitucional. ${ }^{22}$

seu DAER, com a construção da RS-786? Foram, a final, os resultados obtidos com a realização da obra realmente mais expressivos do que os danos provocados ao ecossistema, a ponto de justificá-la? Em suma, houve a alegada lesão ao meio-ambiente, e, na hipótese positiva, justifica ela a segurança, o conforto e a saúde que da obra resultam? Em outras palavras, o bem-estar social decorrente da via pública pronta supera os danos provocados ao meio-ambiente, a ponto de justificar a sua construção? [...] A necessidade da rodovia RS-786 parece evidente e indiscutível, sob todos os aspectos, tanto que o projeto, com início em março de 1987, procurou interligar todos os municípios entre Osório e Torres, com relativa urgência, à vista das péssimas condições de segurança e trafegabilidade da ultrapassada BR-101, visando, ao cabo de tudo, ligar os inúmeros balneários existentes ao longo do trajeto, cujo acesso era um verdadeiro labirinto. Assim, havia absoluto interesse, político e econômico, na execução do projeto, porquanto o acesso aos inúmeros balneários era, até então, por estradas municipais obsoletas e rudimentares, cujo fluxo obviamente aumentava durante o verão. [...] Conforme esclarece o Estado, o objetivo maior de qualquer obra é, no fundo, o bem-estar da coletividade, podendo, contudo, qualquer obra do homem, por insignificante que seja, ocasionar algum tipo de impacto no meio ambiente, pela simples razão de que o modifica...'; mas que, no caso, devido à característica linear da estrada construída, facilmente 'acaba ela se integrando à natureza, sem agredir o meio-ambiente', e que, ao contrário, além de não agredi-lo, reverte em benefício à região, cuja economia gira em torno do turismo, do lazer e do descanso, ganhando todos em tempo e saúde. [...] Através de uma pesquisa realizada com proprietários destas áreas chegou-se á conclusão que a estrada causou um impacto positivo para estas comunidades, já que criou um novo interesse pelas propriedades, em sua maioria não propícias à agricultura convencional.' Quer dizer, a despeito dos danos à vegetação houve melhoria da qualidade de vida da população local e de acesso às praias aos veranistas e turistas, trazendo grande desenvolvimento econômico para a região, inclusive com a construção de inúmeros loteamentos e condomínios de luxo, o que retorna em divisas para os Municípios locais que poderão investir melhor em obras de infraestrutura. Tais circunstâncias estão registradas no documento de fl. 39”. Apelação Cível nº 70000683573, julgada pela $1^{\text {a }}$ Câmara Especial Cível, em 26 de junho de 2001, rel. Des. Roque Joaquim Volkweiss. Disponível em <www.tj.rs.gov.br>. É possível extrair esse mesmo sentido da decisão proferida pela Corte Especial do Superior Tribunal de Justiça ao decidir que "questões relativas a interesse econômico cedem passo quando colidem com deterioração do meio ambiente, se irreversível”. (Lex STJ, vol. 133, p. 94) Mutatis mutandi, se o dano ambiental for reversível, puder ser compensado, ao menos em tese, deve-se aceitar a apropriação do meio ambiente pelo homem como condição para garantir a sua sobrevivência, progresso e desenvolvimento.

${ }^{22}$ Artigo $3^{\circ}$ - Constituem objetivos fundamentais da República Federativa do Brasil: I - construir uma sociedade livre, justa e solidária; II - garantir o desenvolvimento nacional; III - erradicar a pobreza e a marginalização e reduzir as desigualdades sociais e regionais; IV - promover o bem de todos, sem preconceitos de origem, raça, sexo, cor, idade e quaisquer outras formas de discriminação. 
A regra geral da Constituição Federal é o modo privado de produção. ${ }^{23}$ Mas o Constituinte de 1988 não optou pelo sistema liberal em face do enunciado no art. $3^{\circ}$ do texto constitucional antes referido.

A Constituição Federal, em seu art. 173, estabelece que a exploração direta de atividade econômica pelo Estado só será permitida quando necessária aos imperativos da segurança nacional ou a relevante interesse coletivo, enumerando, no art. 177, as atividades sujeitas ao monopólio da União. ${ }^{24}$

Para o atendimento do novo modelo econômico criado pela Carta Política de 1988, foi instituído o Programa Nacional de Desestatização visando a retirada do Estado do exercício das atividades econômicas. ${ }^{25}$

Tem-se, assim, que a regra geral da Constituição Federal é o modo privado de produção (art. 170), sendo a exploração estatal da atividade econômica uma exceção à regra constitucional e somente ocorrerá quando presente as exigências estampadas no art. $173 .^{26}$

Esse entendimento não escapou à apreciação do Supremo Tribunal Federal por

${ }^{23} \mathrm{O}$ art. 170 da CF assegura a todos o livre exercício de qualquer atividade econômica, fundada na valorização do trabalho humano e na livre iniciativa, tem por fim assegurar a todos, existência digna, conforme os ditames da justiça social.

${ }^{24}$ Constituem monopólio da União: I. a pesquisa e a lavra das jazidas de petróleo e gás natural e outros hidrocarbonetos fluidos; II. a refinação do petróleo nacional ou estrangeiro; III. a importação e exportação dos produtos e derivados básicos resultantes das atividades previstas nos incisos anteriores; IV. o transporte marítimo do petróleo bruto de origem nacional ou de derivados básicos de petróleo produzidos no País, bem assim o transporte, por meio de conduto, de petróleo bruto, seus derivados e gás natural de qualquer origem; V. a pesquisa, a lavra, o reprocessamento, a industrialização e o comércio de minérios e minerais nucleares e seus derivados.

${ }^{25} \mathrm{O}$ art. $1^{\circ}$, da Lei ${ }^{\circ}$ 8031/90, define que os objetivos do Programa Nacional de Desestatização são: "I - reordenar a posição estratégica do Estado na economia, transferindo à iniciativa privada atividades indevidamente exploradas pelo setor público; III - permitir a retomada de investimentos nas empresas e atividades que vierem a ser transferidas à iniciativa privada; [...] V - permitir que a administração pública concentre seus esforços nas atividades em que a presença do Estado seja fundamental para a consecução das prioridades nacionais.” Márcio Souza Guimarães esclarece que: “Apesar das conhecidas críticas aos programas de desestatização, é indiscutível que a entrada do capital privado nos setores de infra-estrutura está possibilitando ganhos de eficiência. O tempo e o custo das operações portuárias privatizadas, por exemplo, já tiveram uma queda dramática, embora ainda insuficiente para equiparar os portos brasileiros aos padrões mundiais. E, principalmente, está possibilitando aquilo que de outro modo seria um sonho, dada a exaustão da capacidade de financiamento do Estado: atender às imensas necessidades de investimento em infra-estrutura. Isto é vital do ponto de vista das perspectivas de expansão da economia e traz benefícios diretos para os consumidores. A telefonia é um bom exemplo do papel da iniciativa privada na universalização de serviços que significam, em última análise, acesso à cidadania para os brasileiros. O número de terminais de telefonia móvel saltou de 1,3 milhão em 1995 para 11,6 milhões em setembro de 1999. O uso do celular parecia, no começo, um símbolo de status para a classe média. Mostrou-se rapidamente um instrumento de trabalho para microempresários e trabalhadores autônomos, além de bem-estar para domicílios que ainda teriam de esperar pela instalação de um terminal fixo”. O Estado Empresário e a Nova Ordem Constitucional., Disponível em: <http://www.femperj.org.br/artigos/popup.php?pagina=estadoempresário.php\#topo2>. Acesso em: 16 jul.2006.

${ }^{26}$ Tal como ocorre na Itália segundo a carta Del Lavoro : "somente quando falte ou seja insuficiente a iniciativa privada, ou quando estejam em jogo interesses políticos do Estado, a empresa privada é substituída pela empresa pública com a gestão direta do Estado”, conforme esclarece Alberto Asquini. "Perfis da Empresa”, em texto traduzido por Fábio Konder Comparado. Revista de Direito Mercantil, n 104, out-dez/96, p. 112. 
ocasião do julgamento da Ação Direta de Inconstitucionalidade ${ }^{\circ}$ 562-6, movida pelo Partido Socialista Brasileiro-PSB. ${ }^{27}$

Torna-se elucidativo e esclarecedor o voto do Ministro Carlos Ayres Brito por ocasião do julgamento da Ação Direta de Inconstitucionalidade $n^{0} 1649$, requerida pelo Partido dos Trabalhadores :

“A Constituição já havia dito que atividade econômica, art. 170, parágrafo único, é própria da iniciativa privada. Assim como o serviço público é próprio do Poder Público, atividade econômica é própria da iniciativa privada. São dois comandos claríssimos da Constituição. Entretanto, no art. 173, a nossa Lei das Leis permite que o Estado, em caráter excepcional, quebrante a força do parágrafo único do art. 170, empresarie atividades econômicas e assim concorra com os particulares, mas em casos excepcionas, quando presentes ou o relevante interesse coletivo ou o imperativo da segurança nacional”. ${ }^{28}$

Porém, isto não quer dizer que tenha o Constituinte optado pelo sistema liberal pois, como adverte Eros Roberto Grau, a Carta Política de 1988 adotou "um modelo econômico de bem-estar”. ${ }^{29}$ No mesmo sentido Marcio Souza Guimarães esclarece que "a certa altura se poderia imaginar um retorno ao paradigma de Estado Liberal, na medida em que o particular seria o responsável pelo desenvolvimento econômico. Contudo, a grande diferença é a de que o modelo de Estado traçado é o de Estado Regulador, situado entre o Estado Liberal e Estado Intervencionista”. ${ }^{30}$

Para Heleno Tôrres: “a função precípua do Estado é a realização do bem-estar do cidadão em setores tidos como prioritários e fundamentais, incumbindo-lhe, para alcançar esse fim, intervir nas relações intersubjetivas, como instrumento de garantia de uma convivência social harmoniosa, nos termos do quanto autoriza a própria Constituição". ${ }^{31}$ Egon Moreira esclarece que, em decorrência da reforma administrativa, o Estado retirou-se do cenário empresarial e passou a exercer a regulação das atividades econômicas. ${ }^{32}$

A partir do modelo econômico delineado pela Carta Política de 1988 que impõe ao Estado, como regra, a afastamento da atividade econômica ${ }^{33}$, reservando-a para a

\footnotetext{
${ }^{27}$ STF. Ação Direta de Inconstitucionalidade nº 562-6, Tribunal Pleno, Rel. Min. Ilmar Galvão, julgada em $1^{\circ}$.07.1998, publicada no DJ de 16.10.1998

${ }^{28}$ STF. Ação Direta de Inconstitucionalidade $n^{\circ}$ 1649-1, Tribunal Pleno, Rel. Min. Maurício Correa, julgada em 24.03.2004, publicada no DJ de 28.05.2004.

${ }^{29}$ Eros Roberto Grau. A Ordem econômica na constituição de 1988 (Interpretação e crítica), $3^{\mathrm{a}}$ ed. rev. e ampl., São Paulo : Malheiros Editores, 2000, p. 37.

${ }^{30}$ Márcio Souza Guimarães. O Estado Empresário e a Nova Ordem Constitucional.....

${ }^{31}$ Heleno Taveira Torres. Direito tributário e direito privado : autonomia privada: simulação: elusão tributária. São Paulo : Editora Revista dos Tribunais, 2003, p. 125.

${ }^{32}$ O papel do Estado - esclarece o autor - "não mais é o de proprietário (ou endoregulador), sendo agora um regulador externo ao mercado (ou heteroregulador). Egon Bockmann Moreira. “As Agências Executivas Brasileiras e os Contratos de Gestão”. Estudos de Direito Econômico, p. 238.

${ }^{33}$ É importante fazer a distinção entre ‘atividade econômica' e 'prestação dos serviços públicos' previstos no art. 175 da CF. Na classificação adotada por Eros Grau, a expressão 'atividade econômica’ sempre estará indicando uma atividade produtiva reservada privativamente aos particulares. Eros Grau classifica essa atividade como ‘atividade econômica em sentido estrito' para diferenciá-la dos serviços públicos. Eros Roberto Grau. Obra citada, p. 158.
} 
iniciativa privada, é indispensável que se torne efetiva a existência de condições normais para o regular exercício das atividades produtivas pela iniciativa privada, prevenindo e reprimindo condutas ilícitas, tais como pirataria, concorrência desleal, entre outras, cumprindo, assim, as suas funções constitucionais insertas no art. 174 da Carta Política. ${ }^{34}$

Não se trata de criar medidas protetivas dos interesses particulares e individuais das empresas. Ao contrário, trata-se de afastar as condutas desleais que visam os interesses ilícitos e individuais dos infratores que, quando perpretadas, resultam em prejuízo geral da comunidade. O bem jurídico a ser tutelado é a coletividade, pois, a ordem econômica tem por fim assegurar uma existência digna a todos, na dicção do art. $1^{\circ}$, parágrafo único da Lei no 8.884, de 11.06.1994 em consonância com o caput do art. 170 da Constituição.

Isto ocorre quando uma empresa, sob a complacência estatal, exerce as suas atividades na mais completa informalidade sem reconhecer os direitos trabalhistas, sociais e previdenciários dos seus colaboradores e, conseqüentemente, sem recolher as incidências tributárias das suas operações aos cofres públicos. Tais atividades são realizadas em detrimento da comunidade que vai sofrer os efeitos danosos e deletérios desta iniciativa voltada exclusivamente para o interesse do seu titular.

Portanto, cabe ao Estado, como agente regulador, criar mecanismos que assegurem um ambiente de competição saudável para a atuação e funcionamento das atividades econômicas em condições de normalidade. ${ }^{35}$

Esta regulação não importa em intervenção para determinar o modo de funcionamento ou resulte no controle das atividades produtivas. Os empreendedores são livres para a livre escolha sobre o que, como, quando e quanto produzir. ${ }^{36}$

\footnotetext{
${ }^{34}$ Como agente normativo e regulador da atividade econômica, o Estado exercerá, na forma da lei, as funções de fiscalização, incentivo e planejamento, sendo este determinante para o setor público e indicativo para o setor privado.

${ }^{35}$ Fiscalizar - escreveu Eros Grau - "significa prover a eficácia das normas produzidas e medidas encetadas, pelo Estado, no sentido de regular a atividade econômica. Essas normas e medidas, isso é evidente - nítido como a luz solar passando através de um cristal, bem polido - hão de necessariamente estar e dar concreção aos princípios que conformam a ordem econômica. Eros Roberto Grau. Obra citada, p. 306.

36 “Afirmar a livre iniciativa como base é reconhecer na liberdade um dos fatores estruturais da ordem, é afirmar a autonomia empreendedora do homem na conformação da atividade econômica, aceitando a sua intrínseca contingência e fragilidade; é preferir, assim, uma ordem aberta ao fracasso a uma 'estabilidade' supostamente certa e eficiente. Afirma-se, pois, que a estrutura da ordem está centrada na atividade das pessoas e dos grupos e não na atividade do Estado. Isto não significa, porém, uma ordem do laissez faire, posto que a livre iniciativa se conjuga com a valorização do trabalho humano, mas, a liberdade, como fundamento, pertence a ambos. Na iniciativa, em termos de liberdade negativa, da ausência de impedimentos e da expansão da própria criatividade. Na valorização do trabalho humano, em termos de liberdade positiva, de participação sem alienações na construção da riqueza econômica. Não há, pois, propriamente, um sentido absoluto e ilimitado na livre iniciativa, que por isso não exclui a atividade normativa e reguladora do Estado. Mas há ilimitação no sentido de principiar a atividade econômica, de espontaneidade humana na produção de algo novo, de começar algo que não estava antes. Esta espontaneidade, base da produção da riqueza, é o fator estrutural que não pode ser negado pelo Estado. Se, ao fazê-lo, o Estado a bloqueia e impede, não está intervindo, no sentido de normar e regular, mas está dirigindo e, com isso, substituindo-se a ela na estrutura fundamental do mercado”. Tércio Sampaio Ferraz Jr, citado por Clèmerson Merlin Clève. "Proscrição da Propaganda do Tabaco nos meios de comunicação de massa. Regime constitucional da liberdade de conformação legislativa e limites da atividade normativa de restrição a direitos fundamentais”. Revista dos Tribunais, vol. 845, pp. 121-122.
} 
A liberdade de iniciativa ou livre iniciativa, na locução do texto constitucional, é a projeção da liberdade individual no plano da produção, circulação e distribuição de riquezas, assegurando não apenas a livre escolha das atividades econômicas, mas também a autônoma eleição dos meios mais adequados à consecução dos fins visados. Liberdade de fins e de meios informa o princípio da livre iniciativa, conferindo-lhe um valor primordial, como resulta da interpretação conjugada dos citados arts. $1^{\circ}$ e 170 da Constituição Federal. ${ }^{37}$

Essa liberdade deverá ser exercida em conformidade com o modelo econômico de bem-estar referido por Eros Grau, isto é, levando-se em conta os valores fundantes da ordem constitucional em vigor representados pela valorização do trabalho humano e pela redução das desigualdades sociais, de modo a realizar a tão almejada justiça social.

A expressão "intervenção sensata” cunhada por Egon Moreira revela a dificuldade para identificar a linha tênue que separa, que divide, que limita a licitude do poder regulador do Estado. ${ }^{38} \mathrm{O}$ desafio é encontrar o caminho apaziguador entre as forças que movem a iniciativa privada no modo de produção e funcionamento das atividades econômicas e a função reguladora do Estado, na sua nobre e suprema função de regular e de manter as condições necessárias para o funcionamento normal dessas atividades.

Se o Estado não pode produzir riqueza, porque o modelo econômico reserva esta atividade à iniciativa privada, a empresa surge como núcleo propulsor dos indispensáveis recursos financeiros para que o Estado possa executar as suas políticas públicas resultando, daí, uma íntima correlação entre os papéis do Estado e da empresa visando 0 atendimento das exigências contidas no art. $3^{\circ}$ da Carta Magna na construção de uma sociedade solidária que possa resultar na diminuição da pobreza, na geração de empregos, enfim, na melhoria das condições de vida dos cidadãos. ${ }^{39}$

A cooperação empresa-Estado não se deve limitar apenas no financiamento das políticas públicas. A empresa também pode e deve promover a inclusão social, desenvolvendo programas que privilegiem o emprego do menor aprendiz, de portadores de deficiência, de negros, dos idosos, criando, ainda, programas que visem dar assistência à saúde e complementar a aposentadoria dos seus empregados, dada a reconhecida ineficiência do sistema público, a exemplo das "ações afirmativas do direito norteamericano" $^{\text {40 }}$ como adiante se verificará.

\footnotetext{
${ }^{37}$ Miguel Reale. Temas de direito positivo. São Paulo: RT, p. 250.

${ }^{38}$ Para o autor deve ser "a intervenção estatal na economia importa celebrar não uma desproporção ou uma invasão desmedida, nem tampouco uma abstenção estatal, mas um equilíbrio de forças no próprio mercado em questão - seja de forma a corrigir os desvios constatados na conduta dos agentes, seja instalando uma nova realidade econômica até então inédita. [...] há de ser necessária, ponderada, excepcional e pontual com finalidade pública e específica”. Egon Bockmann Moreira. Obra citada, p. 80 e seguintes.

${ }^{39}$ Gustavo Tepedino sustenta que configuram verdadeira cláusula geral de tutela e promoção da pessoa humana tomada como valor máximo pelo ordenamento, "a escolha da dignidade da pessoa humana como fundamento da República, associada ao objetivo fundamental da erradicação da pobreza e da marginalização e de redução das desigualdades”. (A incorporação dos direitos fundamentais pelo ordenamento brasileiro..., pp. 166-167).

${ }^{40}$ Claudia Lima Marques, com base no constitucionalismo americano que defende ações diferentes e reequilibradoras da discriminação, desenvolve importante estudo envolvendo a concretização do mandamento
} 


\subsection{A práxis solidária da empresa}

Está declarado no pórtico da carta constitucional de 1988 que a República Federativa do Brasil tem por fundamento os valores sociais do trabalho e da livre iniciativa, conforme art. $1^{\circ}$, inciso IV.

Também resulta claro que o desenvolvimento, o progresso ou a modernização devem propiciar melhoria das condições sociais, como por exemplo, a geração de empregos e a distribuição de renda, a partir das premissas insertas no art. $3^{\circ}$ da Carta Constitucional, especialmente aquela que determina como sendo um dos objetivos fundamentais da República Federativa do Brasil a construção de uma sociedade livre, justa e solidária.

Trata-se, pois, de premissa constitucional afirmada no caput do art. 170 da Carta Magna, segundo o qual a ordem econômica deve ser fundada na valorização do trabalho humano.

Mas não é só aumentando as riquezas que a empresa contribui para a melhoria das condições de vida, mas também por meio de uma práxis solidária.

A atividade empresarial também deve produzir efeitos no campo social, impondo à empresa, diante de sua vinculação ao texto constitucional, o dever de executar, ${ }^{41}$ em caráter complementar, programas de inclusão social, promovendo o bem estar dos seus trabalhadores, colaboradores e da comunidade onde se situa, pois - no dizer de Modesto Carvalhosa - “a empresa tem óbvia função social, nela sendo interessados os empregados, os fornecedores, a comunidade em que atua e o próprio Estado, que dela retira contribuições fiscais e parafiscais". ${ }^{42}$

A obtenção de lucro desacompanhado da implantação de programas sociais desatende a exigência constitucional estampada no caput do art. 170, segundo a qual a atividade econômica deve assegurar a todos uma existência digna. ${ }^{43}$

Para o Instituto Ethos de Empresas e Responsabilidade Social, organização não-governamental criada com a missão de mobilizar, sensibilizar e ajudar as empresas a gerir seus negócios de forma socialmente responsável, tornando-as parceiras na construção de uma sociedade sustentável e justa, que congrega mais de 1000 empresas-associadas, ação social significa uma atividade realizada pela empresa:

constitucional da solidariedade social. "Solidariedade na doença e na morte : sobre a necessidade de 'ações afirmativas’ em contratos de planos de saúde e de planos funerários frente ao consumidor idoso.” Constituição, Direitos Fundamentais e Direito Privado / Adalcy Rachid Coutinho... [et. Al]; org. Ingo Wolfgang Sarlet - Porto Alegre : Livraria do Advogado Editoria, 2003, pp. 185-222

${ }^{41}$ Apesar da "problemática em torno da vinculação dos particulares às normas definidoras de direitos e garantias fundamentais” na feliz expressão de Ingo Sarlet, poder-se-ia sustentar a eficácia mediata ou indireta dos direitos fundamentais "como princípios imediatamente conformadores da ordem jurídica, dotados de um efeito irradiante para as relações sociais” sendo que a violação dessa eficácia irradiante corresponderia a uma "ofensa aos direitos fundamentais, passível de dedução em Juízo, inclusive por intermédio do controle das decisões judiciais atentatórias à Constituição”. Obra citada. p. 392 e seguintes.

${ }^{42}$ Modesto Carvalhosa. Comentários à Lei das Sociedades Anônimas, vol. 3, São Paulo : Saraiva, p. 237.

${ }^{43}$ Em oposição ao que sustenta Fabio Ulhoa Coelho: "O empresário visa, com os lucros gerados pela empresa, ter meios para atender as necessidades suas e de sua família, em padrão de vida normalmente bem acima da generalidade das pessoas”. Curso de Direito Comercial, vol. 1, 6. ed. ver. e atual. São Paulo: Saraiva, 2002, p. 187. 
"para atender às comunidades em suas diversas formas (conselhos comunitários, organizações não governamentais, associações comunitárias, etc), em áreas como assistência social, alimentação, saúde, educação, cultura, meio ambiente e desenvolvimento comunitário. Abrange desde pequenas doações a pessoas ou instituições até ações estruturadas, com uso planejado e monitorado de recursos, seja pela própria empresa, por fundações e institutos de origem empresarial, ou por indivíduos especialmente contratados para a atividade". ${ }^{4}$

Portanto, a empresa, além de organizar os fatores de produção, também deve promover e executar ações sociais, criando, assim, a responsabilidade social empresarial. Representam exemplos de iniciativas empresariais a inserção, no estatuto ou contrato social, de dispositivos que assegurem a presença de um representante eleito pelos empregados nos órgãos estatutários da empresa (Conselho de Administração, Diretorias Comitês especiais), a participação dos empregados nos lucros da empresa ou, ainda, a implantação de políticas que incentivem os empregados e colaboradores a fazer doações incentivadas a programas sociais. ${ }^{45}$

É certo que não compete à empresa substituir as funções do Estado a quem cumpre, em primeiro lugar, prover e atender as necessidades básicas assistenciais dos cidadãos. Mas, de outro lado, a ineficiência do Estado também não pode servir de escudo para que a empresa deixe de fazer a sua parte, por menor que seja a sua contribuição.

Cabe também desde logo esclarecer que tais ações sociais devem estar desvinculadas da marca e imagem institucional e corporativa da empresa. Não podem constituir uma jogada de marketing como ocorre, por exemplo, com uma ação social promovida por conhecida multinacional que, a pretexto de repassar o faturamento pela venda dos produtos a uma campanha humanitária, também desenvolve ampla campanha publicitária e atrai consumidores, em geral crianças e adolescentes, para o consumo dos seus produtos, tentando, assim, fidelizá-los.

Ao libertar a empresa das amarras da visão privatista e individualista pretende-se reconstruir a sua verdadeira contribuição da redução das desigualdades e na concretização dos direitos fundamentais. Não são poucos que vêem na empresa uma simples posição

${ }^{44}$ Disponível em <http://www.ethos.org.br/ docs/ conceitos_praticas/indicadores/glossario/>. Acesso em: 17 jul. 2006. Nesse mesmo sentido, Diego Richard Ronconi esclarece que "importa observar que o simples alcance do lucro não deve ser o único objetivo a ser alcançado, pois, se a busca do lucro não estiver revestida de outros valores importantes às relações internas ou externas às empresas, o capitalismo "selvagem" será capaz de dominar todos os ambientes, desde a empresa, até o lar dos funcionários e/ou dos clientes. [...] o objetivo do aumento da riqueza das empresas não pode se restringir ao mero alcance do lucro. O investimento no fator humano torna-se fundamental para um bom resultado na política econômica empresarial." Os códigos de ética e disciplina empresariais e seu impacto na dinâmica da sociedade e na cidadania empresarial. Jus Navigandi, Teresina, ano 8, $\mathrm{n}^{\circ}$ 396, 7.08.2004. Disponível em: <http://jus2.uol.com.br/doutrina/texto.asp?id =5530>. Acesso em: 17 jul. 2006.

${ }^{45}$ As doações ao Funcriança possibilitam a qualificação da rede de atendimento, auxiliam no processo de inclusão de jovens cidadãos que vivem em vulnerabilidade social e em situação de rua e evitam que outras crianças e adolescentes passem a fazer da rua seu local de subsistência e moradia. A dedução de doações ao Funcriança no Imposto de Renda está prevista no art. 260 do Estatuto da Criança e do Adolescente e em legislação tributária específica, que regulamenta a contribuição de pessoas físicas e jurídicas. Assim, a empresa também deveria financiar a doação dos seus empregados e colaboradores ao Funcriança. 
de intermediária entre produtores e consumidores, como uma classe parasitária que nada mais faz do que transmitir riquezas de uma mão para outra.

Waldemar Ferreira coloca a questão nos seus devidos termos ao destacar a importância, a contribuição e as qualidades do comerciante com as seguintes palavras que, apesar de terem sido produzidas há mais de cinqüenta anos, são atualíssimas e, quiçá, poderiam ser consideradas uma verdadeira projeção do futuro:

"Para isso, (o comerciante) encurta as distâncias. Aproxima os povos e as nações. Faz desaparecer as diferenças oriundas das diversidades naturais de regiões de raças e de costumes. Não é só transportador. Nem apenas mediador. Especula. Especulador, amplia a oferta, mas antes aguça a procura. Provoca o desenvolvimento do espírito de iniciativas. Torna os produtos sempre mais baratos e melhores. Criador de utilidades, movimentador de riquezas, instrumento de civilização e de progresso, compra. Prepara. Acondiciona. Transporta. Para transportar, constrói veículos, que percorrem a terra, atravessam os mares e cruzam os ares. Assalaria os seus condutores. Segura as mercadorias contra os riscos de acidentes, de naufrágios, de incêndios. Deposita-as, a fim de distribuí-las e revendê-las. Monta estabelecimentos. Abre bazares e lojas, onde as expõe. Firma contratos com auxiliares e prepostos. Revende a dinheiro e a prazo, emite e aceita títulos de crédito, especialíssimos, munidos de poder circulatório". ${ }^{46}$

Recentemente Fábio Konder Comparato reafirmou a força transformadora da empresa nos seguintes termos: "se se quiser indicar uma instituição social que, pela sua influência, dinamismo e poder de transformação, sirva de elemento explicativo e definidor da civilização contemporânea, a escolha é indubitável: essa instituição é a empresa”." ${ }^{47}$

A empresa, como fonte geradora de riqueza, surge como protagonista de destaque no financiamento das políticas públicas do Estado e como coadjuvante na execução de programas sociais, com a reconstrução do seu perfil social em consonância com os ideais constitucionais e da nova codificação, libertando-a da visão privatista e individualista da codificação revogada, como fonte exclusiva de geração de riqueza para os seus titulares. ${ }^{48}$

Enfim, quando o crescimento econômico e a expansão da atividade industrial apenas privilegiam a adoção de métodos produtivos mais eficazes e o aumento da capacidade da acumulação de riqueza sem levar em consideração os correspondentes impactos socioambientais, assim entendidos como aqueles relacionados à melhoria

\footnotetext{
${ }^{46}$ Waldemar Ferreira. Tratado de Direito Comercial Brasileiro. São Paulo: Saraiva. $1^{\text {o }}$ vol., 1962, pp-474-475

${ }^{47}$ Fabio Konder Comparato. “A reforma da empresa”. Direito Empresarial. São Paulo : Saraiva, 1990, p. 3

${ }^{48}$ A Bolsa de Valores Sociais (BVS) é uma iniciativa lançada pela BOVESPA - Bolsa de Valores de São Paulo - para impulsionar projetos realizados por ONGs brasileiras, visando acima de tudo promover melhorias na perspectiva social do país. Seu principal objetivo é estabelecer um ambiente que privilegie a crença em projetos que mereçam ser apoiados para que dêem certo. A BOVESPA e suas Corretoras associadas apresentam os programas para os investidores, buscando atrair recursos para as ONGs listadas na Bolsa de Valores Sociais. Desse modo, enquanto as organizações fortalecem seus negócios na BOVESPA devolvendo o capital do investidor com lucros e dividendos, as ONGs tornam-se mais fortes e devolvem o investimento na forma de uma sociedade mais justa em que crianças e jovens contam com melhores oportunidades. Esse projeto é reconhecido pela Unesco como único e primeiro do mundo. Disponível em http://www.bovespasocial.com.br/ Português/ABVS.asp. Acesso em 20 jul. 2006.
} 
das condições de vida dos seus trabalhadores, então é possível afirmar que se trata de mau crescimento. ${ }^{49}$

Além dessa importante função coadjuvante desempenhada pela empresa na execução de programas sociais, também é indispensável adequar o processo de produção a um modo ambientalmente satisfatório com a imposição de técnicas industriais que reduzam o lançamento de dejetos e emissões industriais e compensem a sociedade pela melhoria da qualidade de vida.

4.3. Algumas fórmulas para neutralizar ou reduzir os efeitos da atividade econômica sobre o meio ambiente: funções e efeitos

O Estado necessita de recursos financeiros para atender as suas necessidades administrativas das mais variadas atividades. Em face da opção constitucional do não-exercício de atividade econômica pelo Estado, a tributação é o modo pelo qual o sistema jurídico permite-lhe recolher tais recursos junto à sociedade. ${ }^{50}$ Os tributos pagos pela empresa financiam as políticas públicas desenvolvidas pelo Estado.

A relação Estado-contribuinte sempre foi marcada pela polarização e pelo antagonismo: o Estado, como credor e sujeito ativo da obrigação tributária, cada vez mais necessita de recursos financeiros para financiar as suas políticas públicas; o contribuinte, como devedor e sujeito passivo da relação tributária, tende a adotar comportamento lícito para diminuir a tributação por considerar excessiva a carga tributária.

Eis aí o dúplice e antagônico significado da expressão reforma tributária que, para o Estado, representa a possibilidade de aumentar a arrecadação e, ao mesmo tempo, para o contribuinte, uma esperança de redução da elevada carga tributária.

Enquanto o Estado está sujeito às limitações constitucionais consagradas pelos princípios da legalidade, anterioridade, irretroatividade, proibição do confisco insertos no art. 150 da Carta Política de 1988, referidos por Cristiano Carvalho como "freios internos do ordenamento", 51 de outro lado, a empresa poderá organizar as suas atividades

\footnotetext{
49 O Relatório do Desenvolvimento Humano 1996, publicado pela Tricontiental Editora (Lisboa) para o Programa das Nações Unidas para o Desenvolvimento (PNUD), identifica cinco exemplos deste tipo de crescimento: (1) Crescimento sem emprego - a economia em geral cresce, mas falha na expansão das oportunidades de emprego. (2) Crescimento desumano - Os ricos tornam-se mais ricos e os pobres não obtêm nada. (3) Crescimento sem direito a opinião - a economia cresce, mas a democracia/ participação da maioria da população não é respeitada. (4) Crescimento desenraizado - a identidade cultural é submergida ou deliberadamente anulada pelo governo central, como em alguns dos Estados da antiga Iugoslávia ou das áreas Curdas da Turquia e do Iraque. (5) Crescimento sem futuro - os recursos desperdiçados pela geração atual, que irão ser necessários às futuras gerações. Disponível em http://www.pnud.org.br/hdr/hdr96/ hdr1.htm\#bomcresc. Acesso em 29 set. 2006.

${ }^{50}$ Para Cristiano Carvalho "em regimes democráticos, a forma por excelência de interferência do direito na economia é o tributo. Cabe dizer que isso não significa, em essência, um desvalor ou vício de um Estado Democrático de Direito, mas, antes, o custo necessário para tanto. Nesse sentido, Ricardo Lobo Torres esclarece que o preço da liberdade é o tributo, i.e., pois sempre será necessária a existência de um Estado para garantir as liberdades individuais e a forma de financiá-lo é justamente a tributação”. "Tributação e Economia”. Direito e Economia / Hermílio Santos... [et. Al.]; coord. Luciano Benetti Timm - São Paulo: IOB Thomson, 2005, p. 103.

${ }^{51}$ Idem, p. 103
} 
de modo a ter a incidência tributária sobre os seus negócios que melhor atenda à sua capacidade de produção, salvo quando proceder em fraude ou contra a lei.

Se o Novo Código Civil, ao conceituar o empresário o fez para lhe atribuir o exercício profissional e organizado de atividade econômica, conforme prescreve o art. 966, ${ }^{52}$ é natural que o modo pelo qual a empresa irá organizar e estruturar as suas operações deva considerar e avaliar a carga tributária tornando-a compatível com a sua capacidade de desenvolver atividades de maneira próspera e saudável, de modo a cumprir satisfatoriamente a sua relevante missão de gerar e fazer circular riqueza, base para o financiamento das políticas públicas do Estado. ${ }^{53}$

Entende-se que a empresa desorganizada e desestruturada, sem a mínima eficiência econômica, não poderá contribuir na geração dos recursos destinados ao financiamento das políticas públicas do Estado. Ao contrário, representará um ônus para o Estado, pois deixará de cumprir as suas obrigações legais e, conseqüentemente, também desatenderá a sua função social. "Impossível imaginar uma empresa, qualquer empresa, sem organização". ${ }^{4}$

Daí, então, a racionalidade econômica e a eficiência serem necessárias como instrumento para a realização dos fins sociais da empresa, fazendo surgir, então, o planejamento tributário como elemento essencial no funcionamento da empresa, como procedimento, de caráter preventivo, para a escolha da alternativa que acarrete o menor ônus financeiro, entre todas as opções legais existentes ${ }^{55}$.

Mas há limites para a empresa na escolha das alternativas que possam favorecer o desenvolvimento das suas atividades com a economia de impostos. A partir da Lei Complementar $\mathrm{n}^{\circ}$ 104, de 10 de janeiro de 2001, o art. 116 do Código Tributário Nacional, passou a contar com o parágrafo único que concede à autoridade administrativa o poder de "desconsiderar atos ou negócios jurídicos praticados com a finalidade de dissimular a ocorrência do fato gerador do tributo ou a natureza dos elementos constitutivos da obrigação tributária”.

Então, haverá uma linha tênue que separa e que divide a licitude da elisão fiscal, comportamento lícito e não-vedado em lei que visa criar condições razoáveis e

\footnotetext{
52 Art. 966 do Código Civil: Considera-se empresário quem exerce profissionalmente atividade econômica organizada para a produção ou a circulação de bens ou de serviços” que praticamente reproduz o art. 2082 do Código Civil Italiano: È imprenditore chi esercita professionalmente un'attività economica organizzata al fine dela produzione o dello scambio di beni o di servizi..

${ }^{53}$ Nas sociedades por ações reguladas pela Lei $n^{\circ}$ 6.404/76, por exemplo, não se trata nem de opção do administrador, mas de obrigação que a lei lhe impõe ao vedar a "prática de ato de liberalidade à custa da companhia”, conforme previsto no art. 154, § 2º letra “a” da Lei Societária.

${ }^{54}$ A jurista das Arcadas Rachel Sztajn sob o título “Opção do Legislador Brasileiro de 2002” faz um profundo e minucioso estudo comparativo das características da empresa no Código Civil Italiano e no Código Civil Brasileiro de 2002, com apoio nos renomados juristas Vicenzo Buonocore, Alfredo Rocco, Tullio Ascarelli, Francesco Galgano, entre outros. Rachel Sztajn. Teoria jurídica da empresa: atividades empresária e mercados. São Paulo: Atlas, 2004, pp. 109-136.

55 “O atual sistema jurídico brasileiro permite ao contribuinte a utilização do planejamento tributário, de maneira a não pagar tributo ou incidir em uma carga tributária menos onerosa, ou até mesmo atrasar o momento que deva efetuar o pagamento de determinado tributo. Não há obrigatoriedade do contribuinte praticar atos que importem em uma carga tributária mais onerosa dentre as previstas”. Luciano Silva Amaro. Direito Tributário Brasileiro. 8. ed. São Paulo: Saraiva, 2002, p. 225.
} 
adequadas para o pagamento de impostos, da ilicitude da evasão fiscal, que se caracteriza por um comportamento anormal, não-usual, adotado com o fim exclusivo de evitar ou reduzir a incidência tributária como, por exemplo, o abuso de forma, negócios jurídicos indiretos, falta de propósito negocial, entre outros.

A chamada norma anti-elisão representa certa restrição à autonomia privada da empresa na desenfreada economia de tributos, a qualquer custo e no seu exclusivo interesse. Contudo, a empresa não está impedida de desenvolver critérios que possam permitir uma "legítima economia de tributos" na expressão cunhada por Heleno Torres. $^{56}$

Tais critérios podem ser "propriamente jurídicos (norma, valor, justiça, entre outros)" ou "conceitos econômicos (racionalidade econômica, eficiência, etc", conforme sustenta Paulo Caliendo, ${ }^{57}$ mas não poderão ser considerados "como um objetivo ou um valor absoluto, mas, sim, como conceito interdisciplinar, de caráter instrumental, apto a permitir ao direito a busca de melhores soluções para as situações manifestadas no mundo dos fatos". 58

Deve ser afastada a aparente contradição que poderia haver entre a necessidade do Estado na máxima obtenção de recursos para financiar as suas políticas públicas e a eventual economia que pode resultar do planejamento tributário realizado pela empresa; afinal, ao Estado também é vedado arrecadar a qualquer custo e inviabilizar o funcionamento das atividades produtivas da empresa da qual deseja alguma resposta no campo social. ${ }^{59}$

Daí, então, surgir a tributação ambiental que pode assumir função tipicamente arrecadatória com a finalidade de gerar recursos financeiros para o Estado aplicar nas políticas ambientais ou função regulatória com a criação de incentivos que estimulem posturas empresariais comprometidas com o meio ambiente.

Em sede doutrinária trava-se controvérsia. De um lado, Maria Ribeiro e Jussara Ferreira, em obra organizada pelo tributarista Heleno Torres, sustentam que "a tributação

${ }^{56}$ Para o jurista, essa legítima economia de tributos se caracteriza por “atitudes lícitas que possam ser adotadas pelos contribuintes na estruturação ou reorganização dos seus negócios, tendo como finalidade a economia de tributos, evitando a incidência destes, reduzindo ou diferindo o respectivo impacto fiscal, sem qualquer descumprimento frontal ou indireto das leis, são perfeitamente válidas”. Heleno Taveira Torres. Direito Tributário e Direito Privado..., p. 174.

${ }^{57} \mathrm{O}$ autor admite a análise econômica do direito ao reconhecer que "os contratos são formas de permitir a estabilização de expectativas e a previsibilidade das preferências dos agentes econômicos” facultando-se-lhes “a melhor organização das decisões individuais, ou seja, a apresentação da melhor forma para 'vestir' o propósito econômico da operação.” "Direito internacional privado e análise econômica do direito”. Paulo Caliendo. Direito e Economia..., p. 201 e 209.

${ }^{58}$ Carlos Eduardo Pianovski Ruzyk. "A responsabilidade civil por danos produzidos no curso de atividade econômica e a tutela da dignidade da pessoa humana: o critério do dano ineficiente”. Diálogos sobre Direito Civil. Carmem Lucia Silveira Ramos (org.). et. al. - Rio de Janeiro: Renovar, 2002, p. 139.

${ }^{59}$ Á propósito veja-se as seguintes situações exemplificadas por Juarez Freitas ao se referir à "vedação de excesso e de inoperância” na aplicação do princípio da proporcionalidade: "se além da preservação da saúde, erradicar-se nuclearmente o direito à propriedade, em lugar de restrição adequada, aí sim consubstanciar-se-á o ato abusivo e indenizável. Ainda: se, no processo administrativo disciplinar, restar aplicada a penalidade demissória, quando a punição menos dura seria a mais consentânea". "Responsabilidade Objetiva do Estado, Proporcionalidade e Precaução”. Revista da Ajuris, nº 100, p. 11. 
ambiental pode revelar-se um expediente importante para atingir o objetivo de preservação do planeta." 60

Todavia, a tributação ambiental com função tipicamente arrecadatória com a possibilidade de compensar os efeitos da atividade humana sobre o meio ambiente mediante a imposição de um valor monetário da natureza, pode resultar na elitização do meio ambiente e na instituição de um direito de poluir.

Para Cristiane Derani, esse sistema transforma bens naturais de acesso a qualquer pessoa em produtos de luxo apenas para aqueles que teriam disponibilidade e possibilidade para pagar o preço. Argumenta, ainda, que "recursos naturais abundantes teriam preço zero" porque "na abundância não há lucro" para concluir que a escassez ambiental “é uma escassez real, não de mercado” baseada na lei da oferta e da procura. ${ }^{61}$

Talvez o caminho seja a adoção de um planejamento tributário ambiental que vise estimular as empresas a adotarem posturas ambientalmente responsáveis, seja no desenvolvimento das suas atividades com a adoção de mecanismos que restrinjam e diminuam a emissão de poluentes, como também, que recompensem as empresas que decidam cooperar e atuar, em caráter subsidiário à atividade estatal, na recuperação e remediação do meio ambiente degradado por terceiros. ${ }^{62}$

Esses estímulos, em forma de incentivos, além de contribuírem para a proteção e recuperação dos recursos naturais também funcionariam para fomentar o progresso com a geração de empregos, distribuição da renda, aumento da qualidade de vida, enfim, o tão almejado desenvolvimento sustentável, fazendo da política tributária não um fim em si mesma, mas um instrumento que deve servir à realização social.

A Lei Roanet ${ }^{63}$ pode ser considerada uma lei de incentivo ambiental, na medida em que o patrimônio cultural imaterial, prédios históricos, por exemplo, compõe o chamado meio ambiente artificial. ${ }^{64}$

\footnotetext{
${ }^{60}$ Maria de Fátima Ribeiro e Jussara S. Assis Borges Nasser Ferreira. “O papel do Estado no desenvolvimento econômico sustentável: reflexões sobre a tributação ambiental como instrumento de políticas públicas”. Direito Tributário Ambiental / Ricardo Lobo Torres... [et. Al.]; org. Heleno Taveira Torres - São Paulo : Malheiros Editores, 2005, p. 665.

${ }^{61}$ Sob o título "Valor monetário da Natureza e os Efeitos no Mercado" a autora sustenta a "perversidade deste mecanismo" esclarecendo que o ar, por ser um recurso natural abundante, teria preço zero. Cristiane Derani. Obra citada, pp. 111-116.

${ }^{62}$ Maria Ribeiro e Jussara Ferreira referem a "estímulos ou benefícios, entre eles destacando-se aqueles projetos que contemplam planejamentos ambientais que preservem e recuperem o meio ambiente degradado”. Obra citada, p. 671 .

${ }^{63}$ A Lei nº 8.313, de 23.12.1991 instituiu o Programa Nacional de Apoio à Cultura (PRONAC) com a finalidade de captar e canalizar recursos para o setor de modo a (i) contribuir para facilitar, a todos, os meios para o livre acesso às fontes da cultura e o pleno exercício dos direitos culturais e (iv) preservar os bens materiais e imateriais do patrimônio cultural e histórico brasileiro criou o chamado "incentivo à cultura”. De certo modo, o art. 18, letra $g$, ao facultar às pessoas físicas e jurídicas a opção pela aplicação de parcelas do Imposto sobre a Renda, a título de doações ou patrocínios, tanto no apoio direto a projetos culturais apresentados por pessoas físicas ou por pessoas jurídicas de natureza cultural que visem a preservação do patrimônio cultural material e imaterial.

${ }^{64}$ Ou “ambiente urbano”. Edis Milaré. Obra citada, p. 220. Sobre tributação em matéria ambiental consultar minucioso estudo de Heleno Torres sob o título "Da relação entre competências constitucionais tributária e ambiental - os limites dos chamados tributos ambientais”. Direito Tributário Ambiental / Ricardo Lobo Torres... [et. Al.], pp. 96-156. No mesmo sentido Paulo Caliendo “Tributação e Mercado de Carbono”. Obra citada, pp. 872-894.
} 


\section{GLOBALIZAÇÃO}

O século XXI está marcado pela modernização das atividades econômicas, pela evolução dos meios de comunicação e pela velocidade da informação que transformam o mundo, antes delimitado e demarcado por fronteiras terrestres. A sociedade globalizada privilegia a livre circulação financeira, de mercadorias e de pessoas, de "dimensões planetárias". ${ }^{65}$

Os benefícios do fenômeno global são incontáveis: proporciona o avanço da tecnologia, facilita a circulação financeira e a troca de informações real time, maior acesso a produtos e serviços e o compartilhamento de melhorias e descobertas entre países, garantindo o acesso aos subdesenvolvidos, podendo, assim, representar um produto de justiça social.

Contudo, esse mesmo fenômeno pode provocar a perversidade da dominação e da submissão econômica pelos países mais desenvolvidos. ${ }^{66}$ É preciso, pois, cautela no exame dos efeitos desse fenômeno. ${ }^{67}$

Sem dúvida, hoje não é mais possível pensar o mundo sem os avanços da tecnologia (pesquisa sem internet?), os benefícios da livre circulação financeira (entidades financeiras transacionais) e de pessoas (amplo e irrestrito acesso a universidades européias e americanas).

De outra parte, é necessário examinar os efeitos da dominação econômica, inclusive a (in)suficiência do aparato jurídico nacional frente à sociedade globalizada.

65 “O processo de globalização econômica tem se orientado por regras ditadas no chamado Consenso de Washington [..] passou a ser sinônimo das medias econômicas neoliberais voltadas para a reforma e a estabilização de economias emergentes - notadamente latino-americanas. Tem por plataforma o neoliberalismo (mediante a redução das despesas públicas), a flexibilização das relações de trabalho, a disciplina fiscal para eliminar o déficit público, a reforma tributária e a abertura do mercado ao comércio exterior. Esse consenso estimula a transnacionalização dos mercados e a privatização do Estado, condenando os tributos progressivos e os gatos sociais, em prol da austeridade monetária. Pesquisas demonstram que o processo de globalização econômica tem agravado o dualismo econômico e estrutural da realidade latino-americana, com o aumento das desigualdades sociais e do desemprego, aprofundando-se as marcas da pobreza absoluta e da exclusão social”. Flávia Piovesan. "Direitos Humanos e Globalização”. Direito Global. / Oscar Vilhena Vieira [et. Al.] org. Carlos Ari Sundfeld e Oscar Vilhena Vieira - São Paulo : Max Limonad, 1999, p. 195.Ver também Fritjof Capra. O ponto de mutação. 18. ed. São Paulo : Cultrix, 1997, p. 30.

66 “A relação de força entre Estado nacional (poderia político) e os proprietários dos meios de produção (poderio econômico), causadores da globalização da economia e da mobilidade e internacionalização das empresas comerciais, resulta mais favoráveis aos últimos. O equilíbrio keynesiano está quebrado. E, como o êxito da coação jurídica, ou seja, o modo (e o conteúdo) da regulação social, está diretamente limitado por essa relação, o poderio econômico pesa mais sobre as políticas sócio-econômicas internas” conforme André-Noël Roth O Direito em crise: Fim do Estado Moderno?”. Direito e Globalização Econômica Implicações e Perspectivas ./André-Noël Roth.. [et. Al.]; org. José Eduardo Faria - São Paulo : Malheiros Editores, 1996, p. 25.

${ }^{67} \mathrm{O}$ direito precisa encontrar respostas para as seguintes indagações: “¿ Cómo resistirnos ante innovaciones técnicas que van mucho más deprisa que las reformas jurídica y que al no encontrar prohibiciones expresas tienen el campo libre para provocar consecuencias que pueden ser gravosas para la humanidad? ¿Cómo controlar las astucias con las que funcionan las grandes corporaciones jurídicas que el nuevo orden global ha dejado indemnes? ¿No sería mejor ante estos hechos cambiar el adagio jurídico mencionado e institucionalizar que lo que no está expresamente permitido, está prohibido? Joaquín Herrera Flores. "Los Derechos Humanos en el Contexto de la Globalización: Tres Precisiones Conceptuales”. Direitos Humanos e Globalização. Fundamentos e Possibilidades desde a Teoria Crítica. / Antonio Carlos Wolkmer [et. Al.]. Org. Salo de Carvalho - Rio de Janeiro : Lúmen Juris, 2004, p. 71. 
Ulrich Beck, citado por José Rubens Morato Lei e Patryck de Araújo Ayala, destaca que:

"Nesse novo modelo de organização social, o perfil dos riscos distancia-se dos riscos profissionais e empresariais do Estado nacional, identificando-se agora a ameaças globais, supranacionais, sujeitas a uma nova dinâmica política e social. Os macroperigos dessa nova sociedade caracterizam-se: a) por não encontrarem limitações espaciais ou temporais; b) por não se submeterem a regras de causalidade e aos sistemas de responsabilidade; e, sobretudo c) por não ser possível sua compensação, em face do potencial de irreversibilidade de seus efeitos, que anula as fórmulas de reparação pecuniária”. ${ }^{6}$

Se a globalização provocar desigualdades, injustiças e a "miniaturização do Estado", ${ }^{69}$ o direito não pode ficar inerte e deve reagir com todas as suas forças para (r)estabelecer a tão almejada solidariedade, criando condições para que todos tenham uma vida digna de modo que não se transforme em realidade a advertência feita por Celso Antônio Bandeira de Mello no sentido de que os países em desenvolvimento não caiam na "sedução do canto das sereias" dos países desenvolvidos. ${ }^{70}$

Paulo Lobo também adverte que a globalização "procura transformar o globo terrestre em um imenso e único mercado, sem contemplação de fronteiras e diferenças nacionais e locais". Esclarece que o fenômeno "tende a uma padronização e uniformização de condutas" no exclusivo interesse do aumento do lucro das "empresas transnacionais". Conclui que um dos grandes desafios será o de evitar o "notável enfraquecimento do direito nacional, que se torna impotente". ${ }^{71}$

Quanto ao enfraquecimento do direito nacional, vale transcrever o impressionante relato de José Eduardo Faria que, após abordar os pilares de uma sociedade global livre circulação de bens, capital e pessoas - chama a atenção para os seguintes efeitos:

“Ao levar a política a ser substituída pelo mercado como instância de regulação social, em outras palavras, esse fenômeno tornou a autonomia decisória dos

${ }^{68}$ José Rubens Morato Lei e Patryck de Araújo Ayala. Obra citada, p. 18.

${ }^{69}$ Arnaldo Sampaio de Moraes Godoy. Globalização e Direito no Brasil. Jus Navigandi, Teresina, ano 8, no 462, 12.10.2004. Disponível em: <http://jus2.uol.com.br/doutrina/texto.asp?id=5797>. Acesso em: 5 nov. 2006.

70 "Talvez se possa concluir, apenas, que as condições evolutivas para aceder aos valores substancialmente democráticos, como igualdade real e não apenas formal, segurança social, respeito à dignidade humana, valorização do trabalho, justiça social (todos consagrados na bem concebida e mal-tratada Constituição Brasileira de 1988), ficarão cada vez mais distantes à medida em que os Governos dos países subdesenvolvidos e dos eufemicamente denominados em vias de desenvolvimento - em troca do prato de lentilhas constituído pelos aplausos dos países cêntricos - se entreguem incondicionalmente à sedução do canto de sereia proclamador das excelências de um desenfreado néo-liberalismo e de pretensas imposições de uma idolatrada economia global. Embevecidos narcisisticamente com a própria "modernidade", surdos ao clamor de uma população de miseráveis e desempregados, caso do Brasil de hoje, não têm ouvidos senão para este cântico monocórdio, monolítica e incontrastavelmente entoado pelos interessados.” Celso Antônio Bandeira de Mello. A democracia e suas dificuldades contemporâneas. Disponível http://jus2.uol.com.br/doutrina/texto.asp?id=2290 Acesso em 13 nov.2006.

${ }^{71}$ Paulo Luiz Netto Lobo. Direito do Estado federado ante a globalização econômica. Jus Navigandi, Teresina, ano 5, $\mathrm{n}^{\circ}$ 51, out. 2001. Disponível em: <http://jus2.uol.com.br/doutrina/texto.asp?id=2243>. Acesso em: 5 nov.2006. Em outra passagem o autor esclarece: "A globalização econômica, desde a década de oitenta do século vinte, tem apresentado uma característica instigante: seu avanço se dá as expensas dos direitos nacionais, é dizer, da redução dos poderes dos Estados nacionais, máxime no que concerne aos direitos sociais e econômicos”. 
governantes vulnerável a opções feitas em outros lugares sobre as quais têm escasso poder de influência e pressão. [...] Esvaziou a idéia de justiça via política tributária e converteu os cortes de gastos sociais e o encolhimento do Estado em instrumento de redução de direitos e, por conseqüência, da própria cidadania. Pôs em cheque todo um sistema de garantias, proteção e oferta de condições materiais básicas conquistado democraticamente e justificado em nome da equalização de oportunidades."72

A adaptação das economias nacionais aos modelos globalizados vem acarretando a retirada do Estado da posição de Estado-Protetor na área da saúde, da educação, do trabalho e da previdência, ${ }^{73}$ que vêm sendo transferidas para a iniciativa privada mediante a implantação de programas de privatização de empresas públicas, de concessão de serviços públicos, de assistência médica e previdenciária (complementar), deixando clara a diminuição da atuação e proteção estatal nessas áreas. Os efeitos da globalização atingem até a mais popular e mundialmente conhecida festa brasileira: o carnaval. ${ }^{74}$

72 José Eduardo Faria. “A crise do Judiciário no Brasil : notas para discussão. Jurisdição e direitos fundamentais : anuário 2004/2005 - Escola Superior da Magistratura do Rio Grande do Sul - AJURIS; coord. Ingo Wolgang Sarlet. Porto Alegre : Escola Superior da Magistratura: Livraria do Advogado. Ed. 2006, vol. I, tomo I, p. 32

${ }^{73}$ Annelise Steigleder, com apoio em José Rubens Morato Leite e François Ost, esclarece que a questão ambiental foi "marginalizada, pois o Estado, dirigido por políticas de pleno emprego e de maximização da utilização dos fatores da produção, ignorou e deixou de desenhar uma política ambiental com vistas à melhor qualidade de vida. Tornou-se ele próprio, em muitas ocasiões, o poluidor, pois incumbido de dirigir o desenvolvimento. Assim como o Estado Liberal, pautou-se o Estado do Bem-Estar pela regra do acúmulo de capitais e produção de riqueza, ignorando a preservação dos recursos naturais como elemento de uso limitado. O modelo estatal segue individualista e calcado em uma racionalidade de pura apropriação”. Obra citada, p. 46.

${ }^{74}$ Sob o título "Samba muda para atender a novo ritmo capitalista" o jornal Valor Econômico publicou matéria sobre as influências da globalização no carnaval brasileiro. "Em tempos de globalização, o carnaval parece seguir o sentido contrário: ano a ano, as escolas de samba incorporam elementos de culturas internacionais e conformam suas apresentações às exigências de patrocinadores e da mídia. Entre as décadas de 1930 e 1980, os desfiles das escolas de samba do Rio de Janeiro têm como única inspiração temas brasileiros e seguem um ritmo mais cadenciado e melodioso, conforme especialistas ouvidos pelo Valor. A partir dos anos 1990, os desfiles ganham velocidade e incorporam elementos da cultura internacional. Batidas de funk são incorporados ao samba da Viradouro a partir de 2001. No mesmo ano, um astronauta sobrevoa a Sapucaí no desfile da Grande Rio. Uma estátua do Tio Sam (símbolo do patriotismo americano) de calças arriadas até os tornozelos é destaque em um dos carros da São Clemente em 2004. As mudanças ocorrem não apenas nos elementos físicos dos desfiles, mas atingem um dos signos mais tradicionais do Carnaval: os sambas-enredo. Com a presença dos patrocínios privados e o engrandecimento das escolas de samba, algumas características vão se desfazendo e os sambas-enredo passam a abordar temas nacionais e internacionais. O samba perde as modulações e ganha um ritmo de marcha, observa Fred Góes, professor e pesquisador da Faculdade de Letras da Universidade Federal do Rio de Janeiro (UFRJ) e ex-jurado do carnaval carioca.[...] O pesquisador Fred Góes observa que os sambas-enredo também sofrem influência dos patrocínios - ou o desejo das escolas de samba de os atraírem. A Vale do Rio Doce já desfilou, a PDVSA desfilou. O Carnaval é antes de tudo um business. Mas essa mudança não é negativa. Como toda expressão cultural, o samba muda conforme o contexto. O importante é como as escolas de samba absorvem essas novas demandas do mundo globalizado e as devolvem com um sotaque brasileiro, afirma. Na avaliação dos especialistas, mesmo com a mercantilização do carnaval, a festa segue como a principal expressão da cultura brasileira para o mundo. "Como toda expressão cultural, o samba se transforma e se hibridiza, ganhando aspectos globalizados, mas ainda com um tempero tipicamente brasileiro, diz Góes”. Disponível em http://www.valoronline.com.br/valoreconomico/285/empresasetecnologia/empresas/Samba+mda+ para+atender+a+novo+ritmo+capitalista,,,51,4161953.html?highlight=\&newsid=4161953\&areaid=51\&edi tionid=1701 Acesso em 16 fev.2007. 
De outro lado, uma sociedade globalizada, desterritorializada, sem fronteiras e sem limites pode ser um ambiente propício para abusos. No âmbito da proteção do meio ambiente as organizações empresariais de atuação mundial podem impor as suas práticas e políticas, ${ }^{75}$ adotando condutas diferenciadas nos diversos países em que atuam com a transferência de suas responsabilidades ambientais para os países em desenvolvimento que não possuem condições de impor mecanismos de defesa e de proteção, como adiante se verificará.

\subsection{Impactos no Estado socioambiental}

Como dito linhas atrás, hoje não é mais possível pensar o mundo sem os avanços da tecnologia. Porém, a rapidez cada vez maior no desenvolvimento e uso de tecnologias mais avançadas também produz, com a mesma rapidez e velocidade, a obsolescência tecnológica. Então, o que fazer com máquinas e equipamentos que rapidamente se transformam em objetos obsoletos? Exportar para os países subdesenvolvidos.

Este tema não passou desapercebido na Conferência das Nações Unidas sobre o Meio Ambiente e Desenvolvimento, conhecida como ECO 92 (Rio de Janeiro, 14 de junho de 1992).

O princípio 14 estabelece que "os Estados devem cooperar de modo efetivo para desestimular ou prevenir a realocação ou transferência para outros Estados de quaisquer atividades ou substâncias que causem degradação ambiental grave ou que sejam prejudiciais à saúde humana”.

A ameaça dos países em desenvolvimento se transformarem em lixeira dos países ricos já ocupou a agenda da Organização Mundial do Comércio (OMC) em tema protagonizado pelo Brasil. Trata-se da disputa em torno da comercialização de pneus usados e reformados. De um lado, o Brasil que proíbe a importação por óbvias razões ambientais e, de outro, a União Européia que sustenta que essa proibição causa prejuízo para as indústrias que se dedicam a transformar e reformar os pneus usados. ${ }^{76}$

${ }^{75}$ Ricardo Lorenzetti adverte: "Las normas que facilitan el comercio son importantes y deben ser favorecidas, pero ese comercio permite crear grandes conglomerados empresarios con una amplia capacidad de influir sobre los Estados nacionales, de modo que debería regularse la competencia o bien aplicar de un modo más contundente el orden público nacional. Las reglas institucionales del comercio internacional deben ser complementadas aceptando un derecho de protección de los consumidores a escala global. De lo contrario, se profundizan las asimetrías y se crean importantísimas fallas del mercado, así como situaciones de competencia legislativa”. Ricardo Luis Lorenzetti. Tratado de los contratos: parte general/1. ed. Santa Fé: Rubinzal-Culzoni, 2004, p. 29.

${ }^{76}$ A petição apresentada pelo Brasil na OMC contém sólidos fundamentos ambientais para se impor a proibição a referida importação, pois os pneumáticos inservíveis sempre se constituíram em resíduo ambiental que coloca em sério risco a saúde pública e a proteção ao meio ambiente. Se a União Européia fundamenta a sua posição na questão dos prejuízos financeiros de uma atividade econômica, o Brasil, por sua vez, brilhantemente sintetiza a questão da transferência de passivo ambiental de países ricos na seguinte passagem da petição: “O Brasil implementou um programa abrangente para proteger sua população e seu meio ambiente dos perigos causados por resíduos de pneus. A proibição pelo Brasil das importações de pneus usados e reformados é um elemento central desse programa, uma vez que proíbe as importações de pneus de menor ciclo de vida e conseqüentemente reduz a geração de resíduos de pneus no país. Toda vez que o Brasil reforma um pneu consumido em seu território, reduzem-se a acumulação de resíduos de pneus e os riscos associados para a saúde e o meio ambiente. Toda vez que o Brasil importa um pneu reformado, aumentam-se a acumulação de resíduos de pneus e os riscos associados para a saúde e o meio ambiente”. Disponível em http://www.mre.gov.br/português/ministerio/sitios_secretaria/cgc/pneus_primeira_peticao.doc. Acesso em 3 mar.2007. 
Dessa disputa pode resultar um efeito ainda mais perverso e danoso. Se acolhida a posição sustentada pela União Européia, os países em desenvolvimento poderão se transformar em verdadeiros depósitos de entulho, de lixo tecnológico conhecido mundialmente como $e$-waste, cujos efeitos já são sentidos na África.

Empresas americanas e européias, sob o manto de uma ação social, literalmente se livram de milhares de equipamentos ociosos e obsoletos, transformando os países pobres em depósitos desses equipamentos. Os países donatários assumem e recebem os danosos impactos e efeitos ambientais, suportando os elevados custos da recuperação do meio ambiente, cujos recursos financeiros são tão caros e escassos para a solução de questões sociais já enfrentadas e solucionadas pelos países desenvolvidos. ${ }^{77}$

Urge, pois, proteger os indivíduos que tiveram o infortúnio de pertencerem de viverem nos chamados países pobres ou subdesenvolvidos. São pessoas duplamente penalizadas: além de não terem acesso aos benefícios sociais garantidos pelos países desenvolvidos (trabalho, educação, moradia, saúde, assistência social, etc.), nos países em que vivem os seus escassos recursos financeiros são utilizados, ou melhor, desviados para reparar os danos causados ao meio ambiente pelos equipamentos inservíveis que receberam dos países desenvolvidos. ${ }^{78}$

\subsection{O exemplo alemão}

Mas vem do além-mar o exemplo da Alemanha. País conhecido pela abundância dos bosques - estima-se que 30\% do seu território é ocupado por bosques - onde surge a gestão sustentável do meio ambiente no começo do Século XIX como conseqüência da devastação florestal ocorrida no Século XVIII (desmatamento, exploração de pastos, etc.).

A Lei Federal dos Bosques de 1975 (Bundeswaldgesetz) estabeleceu o princípio da multifuncionalidade dos bosques que, segundo Rehbinder, deve assegurar duas funções:econômica (exploração da madeira) e social (recreativa). ${ }^{79}$

${ }^{77}$ De acordo com o Programa das Nações Unidas para o Meio Ambiente, o volume desse lixo é de 20 a 50 milhões de toneladas por ano no mundo. São montanhas de celulares, baterias, computadores, televisores e impressoras. O relatório Lixo Digital: exportando abusando da África, divulgado em 2005 mostra que equipamentos inúteis são doados ou vendidos para países em desenvolvimento como forma de se livrar dos gastos de reciclá-los devidamente. O estudo foi desenvolvido pela Basel Action Network (www.ba.org) organização sediada em Seattle (EUA) com foco na Nigéria. Nesse país chegam todo mês 500 contêineres, cada um deles com aproximadamente 800 equipamentos, sendo que 75\% estão quebrados e não podem ser consertados. De acordo com o Conselho Nacional de Segurança dos Estados Unidos, mais de 63 milhões de computadores ficarão obsoletos em 2005 nos EUA. Um monitor de computador pode conter 3,5 quilos de chumbo, além de cádmio, substâncias perigosas para o ambiente e humanos. Em 2002, a BAN foi co-autora de um relatório que concluiu que 50\% a $80 \%$ dos eletrônicos coletados para reciclagem nos EUA são reciclados em situações irregulares e insalubres na China, na Índia, no Paquistão e em outros países em desenvolvimento. Revista Adiante. Inovação para a Sustentabilidade. $\mathrm{n}^{\circ}$ 8, agosto 2006, p. 38. Ver também: EUA manda para África seu lixo eletrônico. Disponível em http://www.link.estadao.com.br/index.cfm?id_conteudo=5366. Acesso em 2 mar.2007. EUA mandam PCs inúteis para nações pobres. Disponível em http://www.forumpcs.com.br.noticia.php?b=134313. Acesso em 2 mar.2007. ${ }^{78}$ Embora Ingo Sarlet reconheça as dificuldades da positivação dos denominados "direitos fundamentais da terceira dimensão" consagrados apenas em tratados e documentos internacionais, destaca que os direitos de solidariedade e fraternidade representam "novas reivindicações fundamentais do ser humano, geradas, dentre outros fatores, pelo impacto tecnológico, pelo estado crônico de beligerância”. Obra citada. p. 58.

${ }^{79}$ Eckard Rehbinder. “Direito Florestal e Desenvolvimento Sustentável: uma proposta alemã”. Desafios do Direito Ambiental no Século XXI. Estudos em homenagem a Paulo Affonso Leme Machado. Sandra Akemi Shimana Kishi ... [et. Al.] organizadores. São Paulo: Malheiros Editores. 2005, p. 87. 
A gestão apropriada sustentável impõe a proibição de corte de árvores jovens e exige prévia licença para proceder ao corte autorizado. Porém, “permite à Administração e aos proprietários privados uma margem de discrição e de aplicação política ou econômica", revelando certa prevalência da função econômica com crescimento das preocupações ambientais e sociais ao admitir a possibilidade de certa apropriação da natureza pelo homem abrindo as portas para permitir o desenvolvimento sustentável. ${ }^{80}$

Vê-se, pois, que esse formidável paradigma internacional poderia servir de exemplo para as autoridades brasileiras no trato desta conflituosa relação entre o desenvolvimento das atividades econômicas e a proteção ao meio ambiente.

6. DESENVOLVIMENTO SUSTENTÁVEL: SIGNIFICADO, DIMENSÕES E FATORES A PONDERAR

A idéia de desenvolvimento sustentável começa a surgir no final do século XX, quando se constata que o desenvolvimento econômico também deveria considerar o equilíbrio ecológico e a preservação da qualidade de vida das pessoas. Os recursos naturais deveriam ser apropriados de acordo com a sua capacidade de renovação para evitar o esgotamento. ${ }^{81}$

No início da década de 1980, a Organização das Nações Unidas (ONU) criou a Comissão Mundial sobre o Meio Ambiente e Desenvolvimento, para debater as questões ambientais sob a liderança da primeira-ministra da Noruega, Gro Harlem Brundtland. O documento final desses estudos ficou conhecido como Nosso Futuro Comum ou Relatório Brundtland.

Apresentado em 1987 com uma visão crítica do modelo de desenvolvimento dos países industrializados e reproduzido pelas nações em desenvolvimento, o relatório aponta os riscos do uso exagerado dos recursos naturais sem considerar a sua capacidade de regeneração e propõe uma série de melhorias para a utilização e preservação dos recursos naturais de modo que o desenvolvimento sustentável seja "aquele que atende às necessidades do presente sem comprometer a possibilidade de as gerações futuras atenderem às suas necessidades". ${ }^{82}$

Para Elmar Altvater, o desenvolvimento “deve ser economicamente eficiente,

\footnotetext{
${ }^{80}$ Idem. Ibidem.

${ }^{81} \mathrm{O}$ economista Clóvis Cavalcanti sustenta que desenvolvimento sustentável é literalmente contraditório: "Qualquer melhoria econômica, sob a égide que o homem procura, significa acumulação de capital e o esgotamento de alguma categoria de recursos não-renováveis - como os combustíveis fósseis. A expansão de áreas urbanas unicamente, junto com a construção de estradas, consome cada ano, em todo mundo, em torno de 6 mil quilômetros quadrados de terra arável, em geral as mais preciosas. Dessa maneira, o desenvolvimento tal como vivenciado pelo planeta, não pode ser literalmente sustentável”. "Sustentabilidade da economia: paradigmas alternativos de realização econômica”. Desenvolvimento e natureza: estudos para uma sociedade sustentável. Clóvis Cavalcanti. org. São Paulo: Cortez editoria. 2001, pp. 159-160.

${ }^{82}$ Cristiane Derani. Obra citada, p. 126. Entre nós o Estatuto da Cidade (Lei ${ }^{\circ} 10.257$, de 10.07.2001) estabelece normas de ordem pública e interesse social que regulam o uso da propriedade urbana em prol do bem coletivo, da segurança e do bem-estar dos cidadãos, bem como do equilíbrio ambiental. (art. $1^{\circ}$, parágrafo único) e define que a política urbana tem por objetivo ordenar o pleno desenvolvimento das funções sociais da cidade e da propriedade urbana, assegurada a garantia do direito a cidades sustentáveis, entendido como o direito à terra urbana, à moradia, ao saneamento ambiental, à infra-estrutura urbana, ao transporte e aos serviços públicos, ao trabalho e ao lazer, para as presentes e futuras gerações (art. $2^{\circ}$, inciso I).
} 
ecologicamente suportável, politicamente democrático e socialmente justo”. O título auto-explicativo “a palavra mágica sustentável, ou a quadratura do círculo” bem revela o ceticismo do autor em torno do vocábulo sustentável. Para o autor não é possível haver sustentabilidade com a conjugação de eficiência econômica ameaçada, participação democrática reduzida e justiça distributiva ausente. Para ele, "seria como a realização da quadratura do círculo”. ${ }^{83}$

Em oposição a Altvater, o jurista nacional Édis Milaré esclarece que está “superada a noção romântica de que a natureza é um intocável santuário”. De acordo com o autor brasileiro, outras questões estruturais precisam ser obtemperadas. Sustenta, com muita propriedade que o Brasil

“[...] precisa gerar riquezas para enfrentar os desafios da mudança social, cujos símbolos mais evidentes são a taxa de crescimento da população e a consolidação de uma pobreza estrutural. Há brasileiros vivendo em situação de miséria extrema. Urge melhorar suas vidas, dando-lhes condições mais dignas”. ${ }^{84}$

A adoção, no Brasil, de critérios e restrições ambientais aceitos e reconhecidos em países desenvolvidos pode provocar uma distorção para o atendimento das atuais necessidades dos brasileiros. ${ }^{85}$ Dúvida não há que os países desenvolvidos e os chamados países em desenvolvimento possuem diferentes questões sociais a serem resolvidas. ${ }^{86}$

A consciência e as exigências em matéria ambiental nos países desenvolvidos assumem posição de maior destaque porque outras questões sociais - como emprego, educação, saúde, moradia, previdência social - já foram resolvidas talvez até com desmedido crescimento das atividades produtivas e industriais que gerou a necessária base de arrecadação para o Estado resolver essas questões sociais.

${ }^{83}$ Elmar Altvater. O Preço da Riqueza. Pilhagem ambiental e a nova (des)ordem mundial; tradução de Wolgang Leo Maar. São Paulo: Editora da Universidade Estadual Paulista, 1995, pp. 281-299

${ }^{84}$ Édis Milaré. Obra citada, p. 43. O autor discorre sobre as contradições e princípios da vida sustentável, destacando os seguintes princípios: 1) respeitar e cuidar da comunidade dos seres vivos; 2) melhorar a qualidade de vida humana; 3) conservar a vitalidade e a diversidade do planeta terra; 4) minimizar o esgotamento de recursos não renováveis; 5) permanecer nos limites da capacidade de suporte do planeta terra; 6) modificar atitudes e práticas pessoais; 7) permitir que as comunidades cuidem de seu próprio meio ambiente; 8) gerar uma estrutura nacional para a integração de desenvolvimento e conservação; e 9) constituir uma aliança global. Obra citada, pp. 41-60.

${ }^{85}$ Nesse sentido decisão judicial do Tribunal Regional Federal da 4 a Região admitiu que "toda a atividade humana pode causar danos ao meio ambiente, não há 'poluição zero', de forma que a idéia de natureza intocada é um mito moderno” para, em seguida, destacar essa distorção: “é sabido que o poder público, em especial nos países em desenvolvimento, mal consegue manter os serviços essenciais como saúde e segurança, sendo tradicionalmente um administrador ambiental pouco eficiente e carente de recursos, e sem a participação do empresariado e das coletividades é quase impossível obter progressos nesta questão”. TRF 4a Região, Agravo de Instrumento n ${ }^{\circ}$ 1998.04.02.026742-3/SC, Rel. ${ }^{a}$ Desemb. ${ }^{a}$ Federal Marga Barth Tessler.

${ }^{86}$ Stiglitz ao relatar as suas experiências como economista-chefe e vice-presidente do Banco Mundial ao comentar o modo de agir da instituição e do FMI com o envio de missões para os países em situação de ajuda que se instalam confortavelmente nas capitais, adverte: "não se pode conhecer uma nação, e amá-la, a não ser que se vá para o interior”. Joseph E. Stiglitz. A globalização e seus malefícios. Tradução Bazán Tecnologia e Lingüística - São Paulo: Futura. 2002, p. 51. No mesmo sentido o princípio 11 da Conferência das Nações Unidas sobre o Meio Ambiente e Desenvolvimento, a ECO 92 (Rio de Janeiro, 14 de junho de 1992) alerta que "padrões utilizados por alguns países podem resultar inadequadamente para outros, em especial países em desenvolvimento, acarretando custos sociais e econômicos injustificados”. 
De outro lado, sabe-se que o atual nível de poluição no mundo é resultado do processo de industrialização dos países ricos que, para evitar os esforços que teriam que fazer para recuperação do meio ambiente, utilizam a estratégia de despertar elevado nível de consciência e preocupação ambiental nos países pobres para conter o processo de desenvolvimento e industrialização, transferindo-lhes, inclusive, a responsabilidade ambiental que não lhes pertence. ${ }^{87}$

Enfim, é possível afirmar que há desenvolvimento sustentável quando a política de crescimento da atividade industrial atende às necessidades humanas elementares e imediatas desde que a velocidade e o ritmo dessa expansão não comprometam a possibilidade de as gerações futuras atenderem a iguais necessidades. ${ }^{88}$

É certo que a geração atual não pode impedir ou dificultar que as gerações futuras possam atender às suas necessidades. Mas também é certo que a geração atual tem o dever de legar para as gerações futuras condições materiais para uma vida melhor. Tão grave quanto herdar recursos naturais destruídos ou deteriorados, será o legado de um estado geral de pobreza, desemprego, falta de assistência à saúde, educação e assistência social que podem ser total ou parcialmente erradicados com a expansão das atividades industriais.

\section{CONCLUSÕES}

A doutrina e a jurisprudência levantam vozes e forças na combativa e intransigente defesa do meio ambiente, deixando transparecer que a atuação da empresa possui o estigma da destruição e da deterioração da natureza.

Todavia, a empresa exerce importante papel para a efetividade dos direitos fundamentais declarados no art. $3^{\circ}$ da Carta Política, pois o emprego, o trabalho e o salário contribuem para erradicar a pobreza e reduzir as desigualdades sociais.

A atividade produtiva da empresa exerce importante função ao fazer circular riqueza e, consequentemente, assegurar ao Estado os recursos financeiros necessários à execução e implementação das suas políticas públicas. A empresa também adota práxis que promove, em caráter suplementar, a inclusão social com a realização de programas de assistência à saúde e de previdência complementar.

De outra parte, constata-se que o próprio ser humano trata a natureza com descaso e desconsideração bastando ver que a grande causa de enchentes e inundações nas grandes capitais brasileiras em períodos de chuvas, é o acúmulo de lixo não-degradável deixado nas ruas pela população, cuja conduta constitui literal violação do art. 226, $\S 1^{\circ}$, VI da Constituição Federal.

${ }^{87}$ Conforme José Afonso da Silva. Direito Ambiental Constitucional. São Paulo: Malheiros Editores, 2004, p. 25. 88 "Nenhum país possui uma receita de desenvolvimento que possa ser oferecida, de forma direta, a outro país. Não existe o melhor caminho e, mesmo nesta era de globalização, cada país tem que encontrar seu próprio e específico caminho para pôr em movimento e sustentar o crescimento econômico. Mesmo assim, pela comparação de diferentes experiências, cada sociedade pode aperfeiçoar a compreensão de seus próprios recursos e de suas próprias dificuldades”. Arnaldo Bagnasco. “A teoria do desenvolvimento e o caso italiano”. Raízes e ficções do desenvolvimento / organizadores Glauco Arbix, Mauro Zilbovicius, Ricardo Abramovay. São Paulo: Editora Unesp, Edusp, 2001, p. 349. O texto faz um exame das diferenças de desenvolvimento entre as regiões Norte e Sul daquele país, suas causas, condições e soluções. 
Dados os importantes princípios e valores que envolvem a intrincada relação do meio ambiente com o desenvolvimento econômico, forçoso reconhecer qualquer proposta de solução não comporta a adoção dos mecanismos tradicionais.

Forçoso reconhecer que o conflito entre a proteção do meio ambiente e a expansão das atividades empresariais ou vice-versa, caracteriza uma situação de hard case exigindo a aplicação dos critérios definidos por Dworkin, ${ }^{89}: 1$ ) ausência de regra para solução do caso, já que não é possível afirmar que sempre deva prevalecer a proteção ao meio ambiente em detrimento da expansão das atividades empresariais ou vice-versa; 2) incidência de normas de caráter aberto, cujo conteúdo são preenchidos segundo as circunstâncias de cada caso concreto e a dinâmica da vida social, como por exemplo, a necessidade da construção de uma rodovia para melhorar as condições de vida do ser humano, em detrimento do natureza, como se viu no julgado da Estrada do Mar; e 3) vários princípios são aplicáveis ao mesmo tempo, como o declarado no pórtico dos princípios gerais da atividade econômica (art. 170, caput, da CF) que consagra, a um só tempo, a liberdade do empreendimento e a valorização do trabalho humano.

A idéia de desenvolvimento sustentável vai além do desenvolvimento econômico do qual apenas decorre aumento do fluxo de bens e serviços mais rápido que a expansão demográfica. É necessário compatibilizar as atividades econômicas (art. 170 da CF) com a defesa do meio ambiente (art. 170, VI e art. 225 da CF) e a propriedade privada com a função socioambiental (arts. 182 e 186 da CF), visando a transformação da sociedade e, sobretudo, cumprimento das diretrizes insertas no art. $3^{\circ}$ da Constituição Federal de modo a construir uma sociedade livre, justa e solidária (I) e garantir o desenvolvimento nacional (II). Portanto, o desenvolvimento deixa de ser uma questão econômica.

Enfim, busca-se a desafiante missão de redescobrir o importante papel que a empresa deve desempenhar como elo entre o Estado e os cidadãos, para construir as condições econômicas e sociais que assegurem a efetividade dos direitos fundamentais. ${ }^{90}$

${ }^{89}$ Ronald Dworkin. Levando os Direitos a Sério. Tradução de Nelson Boeira. São Paulo: Martins Fontes, 2002, pp. 129-202.

${ }^{90}$ As comoventes palavras de Eugênio Facchini Neto bem retratam a importância dessa tarefa: “auxiliar na construção de um Brasil mais justo e solidário, com vida em abundância para todos, como queria Cristo, ou com vida digna para cada um, como desejou o constituinte, pode parecer sonho, algo muito distante, ou uma utopia. Concedendo que seja um sonho: como vamos realizar nossos sonhos se não os tivermos sonhado primeiro. Concedendo que seja algo muito distante: que tristes seriam os caminhos se não fora a presença distante das estrelas! como lembrava Quintana. Seria quiçá uma utopia? Recordemos então Eduardo Galeano, que comparava as utopias ao horizonte : se eu avanço um passo, o horizonte recua um passo; se eu avanço dois passos, o horizonte recua dois passos; eu avanço cem metros, o horizonte recua cem metros; eu subo a colina e o horizonte se esconde atrás da colina seguinte. Mas então, perguntava ele, para que servem as utopias? Servem para isso, para nos fazer caminhar!" "Reflexões histórico-evolutivas sobre a constitucionalização do direito privado”. Constituição, Direitos Fundamentais e Direito Privado / Adalcy Rachid Coutinho... [et. Al]; org. Ingo Wolfgang Sarlet - Porto Alegre : Livraria do Advogado Editora, 2003, pp.55-56. Esse mesmo sentido foi dado por Jacques Marcovitch então reitor da Universidade de São Paulo no discurso proferido na cerimônia de entrega da medalha de Honra ao Mérito ao economista e professor Celso Furtado ao referir que o homenageado "é uma das maiores referências da utopia brasileira - se entendermos utopia como ideário e não como um sonho impossível”. Razões e ficções do desenvolvimento/ organizadores Glauco Arbix, Mauro Zilbovicius, Ricardo Abromovay. São Paulo: Editora Unesp, Edusp, 2001, p. 29. 